\title{
Biomass burning at Cape Grim: exploring photochemistry using multi-scale modelling
}

\author{
Sarah J. Lawson ${ }^{1}$, Martin Cope ${ }^{1}$, Sunhee Lee ${ }^{\mathrm{a}, \dagger}$, Ian E. Galbally ${ }^{1}$, Zoran Ristovski ${ }^{2}$, and Melita D. Keywood ${ }^{1}$ \\ ${ }^{1}$ Commonwealth Scientific and Industrial Research Organisation, Climate Science Centre, Aspendale, Australia \\ ${ }^{2}$ International Laboratory for Air Quality \& Health, Queensland University of Technology, Brisbane, Australia \\ ${ }^{a}$ formerly at: Commonwealth Scientific and Industrial Research Organisation, Climate Science Centre, Aspendale, Australia \\ $\dagger$ deceased
}

Correspondence to: Sarah J. Lawson (sarah.lawson@csiro.au)

Received: 18 October 2016 - Discussion started: 5 December 2016

Revised: 6 July 2017 - Accepted: 8 August 2017 - Published: 5 October 2017

\begin{abstract}
We have tested the ability of a high-resolution chemical transport model (CTM) to reproduce biomass burning (BB) plume strikes and ozone $\left(\mathrm{O}_{3}\right)$ enhancements observed at Cape Grim in Tasmania, Australia, from the Robbins Island fire. The CTM has also been used to explore the contribution of near-field BB emissions and background sources to $\mathrm{O}_{3}$ observations under conditions of complex meteorology. Using atmospheric observations, we have tested model sensitivity to meteorology, BB emission factors (EFs) corresponding to low, medium, and high modified combustion efficiency (MCE), and spatial variability. The use of two different meteorological models (TAPM-CTM and CCAMCTM) varied the first (BB1) plume strike time by up to $15 \mathrm{~h}$ and the duration of impact between 12 and $36 \mathrm{~h}$, and it varied the second (BB2) plume duration between 50 and $57 \mathrm{~h}$. Meteorology also had a large impact on simulated $\mathrm{O}_{3}$, with one model (TAPM-CTM) simulating four periods of $\mathrm{O}_{3}$ enhancement, while the other model (CCAM) simulating only one period. Varying the BB EFs, which in turn varied the non-methane organic compound (NMOC) / oxides of nitrogen $\left(\mathrm{NO}_{x}\right)$ ratio, had a strongly non-linear impact on simulated $\mathrm{O}_{3}$ concentration, with either destruction or production of $\mathrm{O}_{3}$ predicted in different simulations. As shown in previous work (Lawson et al., 2015), minor rainfall events have the potential to significantly alter EF due to changes in combustion processes. Models that assume fixed EF for $\mathrm{O}_{3}$ precursor species in an environment with temporally or spatially variable EF may be unable to simulate the behaviour of important species such as $\mathrm{O}_{3}$.
\end{abstract}

TAPM-CTM is used to further explore the contribution of the Robbins Island fire to the observed $\mathrm{O}_{3}$ enhancements during BB1 and BB2. Overall, TAPM-CTM suggests that the dominant source of $\mathrm{O}_{3}$ observed at Cape Grim was aged urban air (age $=2$ days), with a contribution of $\mathrm{O}_{3}$ formed from local BB emissions.

This work shows the importance of assessing model sensitivity to meteorology and $\mathrm{EF}$ and the large impact these variables can have in particular on simulated destruction or production of $\mathrm{O}_{3}$ in regional atmospheric chemistry simulations. This work also shows the importance of using models to elucidate the contribution from different sources to atmospheric composition, where this is difficult using observations alone.

\section{Introduction}

Biomass burning (BB) makes a major global contribution to atmospheric trace gases and particles, with ramifications for human health, air quality and climate. Directly emitted species include carbon monoxide $(\mathrm{CO})$, carbon dioxide $\left(\mathrm{CO}_{2}\right)$, oxides of nitrogen $\left(\mathrm{NO}_{x}\right)$, primary organic aerosol, non-methane organic compounds (NMOCs) and black carbon (BC), while chemical transformations occurring in the plume over time lead to formation of secondary species such as $\mathrm{O}_{3}$, oxygenated NMOC and secondary aerosol. Depending on a number of factors, including magnitude and duration of fire, plume rise, and meteorology, the impact of $\mathrm{BB}$ plumes on human health, air quality and climate may be local, regional or global. 
BB plumes from wildfires, prescribed burning, and agricultural and trash burning can have a major impact on air quality in both urban and rural centres (Keywood et al., 2015; Luhar et al., 2008; Reisen et al., 2011; Emmons et al., 2010; Yokelson et al., 2011) and regional-scale climate impacts (Andreae et al., 2002; Keywood et al., 2011b; Artaxo et al., 2013; Anderson et al., 2016). In Australia, BB from wild and prescribed fires impacts air quality in both rural and urban areas (Keywood et al., 2015, 2011a; Reisen et al., 2011; Luhar et al., 2008) as well as indoor air quality (Reisen et al., 2011). More generally, as human population density increases, and as wildfires become more frequent (Flannigan et al., 2009; Keywood et al., 2011b), assessing the impact of BB on air quality and human health becomes more urgent (Keywood et al., 2011b; Reisen et al., 2015). In particular, particles emitted from BB frequently lead to exceedances of air quality standards, and exposure to BB particles has been linked to poor health outcomes including respiratory effects, cardiovascular disease and mortality (Reisen et al., 2015; Reid et al., 2016; Dennekamp et al., 2015). There is also increasing evidence that mixing of $\mathrm{BB}$ emissions with urban emissions results in enhanced photochemistry and production of secondary pollutants such as secondary aerosol and $\mathrm{O}_{3}$ (Jaffe and Wigder, 2012; Akagi et al., 2013; Hecobian et al., 2012), which may result in more significant health impacts than exposure to unmixed $\mathrm{BB}$ or urban emissions.

To be able to accurately predict and assess the impact of BB on human health, air quality and climate, models must be able to realistically simulate the chemical and microphysical processes that occur in a plume as well as plume transport and dispersion. In the case of BB plumes close to an urban centre or other sensitive receptor, models can be used to mitigate risks on community by forecasting where and when a BB plume will impact, the concentrations of toxic trace gases and particles in the plume, and potential impact of the BB plume mixing with other sources. Models also allow investigation of the contributions from $B B$ and other sources to observed air quality when multiple sources are contributing. Understanding the relative importance of different sources is required when formulating policy decisions to improve air quality.

Lagrangian parcel models are often used to investigate photochemical transformations in BB plumes as they are transported and diluted downwind (Jost et al., 2003; Trentmann et al., 2005; Mason et al., 2006; Alvarado and Prinn, 2009; Alvarado et al., 2015), while three-dimensional (3-D) Eulerian grid models have been used to investigate transport and dispersion of plumes, plume age, and contributions from different sources. Three-dimensional Eulerian grid models vary from fine spatial resolution on the order of a few kilometres (Luhar et al., 2008; Keywood et al., 2015; Alvarado et al., 2009; Lei et al., 2013) to a resolution of up to hundreds of kilometres in global models (Arnold et al., 2015; Parrington et al., 2012).
Sensitivity studies have allowed the influence of different model components (emissions, plume rise, transport, chemistry) on model output to be investigated. Such studies are particularly important in formation of secondary species such as $\mathrm{O}_{3}$, which have a non-linear relationship with emissions. Studies have found that modelled $\mathrm{O}_{3}$ concentration from $\mathrm{BB}$ emissions is highly dependant on a range of factors including (a) meteorology (plume transport and dispersion) in global (Arnold et al., 2015) and high-resolution (Lei et al., 2013) Eulerian grid models, (b) absolute emissions and/or biomass burned (Pacifico et al., 2015; Parrington et al., 2012), (c) model grid size resulting in different degrees of plume dilution (Alvarado et al., 2009), and oxidative photochemical reaction mechanisms in Lagrangian parcel models (Mason et al., 2006).

Broadly speaking, models used for simulating BB plumes comprise (a) a description of the emission source, (b) a determination of plume rise, (c) treatment of the vertical transport and dispersion and (d) a mechanism for simulating chemical transformations in the plume (Goodrick et al., 2013). There are challenges associated with accurately representing each of these components in BB modelling. The description of the emission sources includes a spatial and temporal description of the area burnt, the fuel load, combustion completeness, and trace gas and aerosol emission factors (EFs) (mass of species emitted per mass of fuel burned). The area burned is often determined by a combination of hotspot and fire scar data, determined from retrievals from satellite (Kaiser et al., 2012; Reid et al., 2009; Giglio et al., 2013). Cloud cover may lead to difficulties in obtaining area burnt data, while scars from small fires may be difficult to discern against complex terrain, and low intensity fires may not correspond with a detectable hotspot (Meyer et al., 2008). Emission factors are determined experimentally using either field or laboratory measurements and are typically grouped by biome type. In some regions, such as SE Australia, biomes have been sparsely characterised (Lawson et al., 2015). Furthermore, models use biome-averaged EFs, which do not account for complex intra-biome variation in EFs as a result of temporal and spatial differences in environmental variables. This includes factors such as impact of vegetation structure, monthly average rainfall (van Leeuwen and van der Werf, 2011) and the influence of short-term rainfall events (Lawson et al., 2015). For example, EFs have been shown to vary significantly with fuel moisture, which can vary seasonally (Korontzi et al., 2003; Urbanski, 2013). There may be significant spatial variability in EFs within a biome (Castellanos et al., 2014); taken along with temporal variability, this has been shown to have a large impact on simulated concentrations of BB species in globalscale modelling (van Leeuwen et al., 2013).

Finally, the very complex mixture of trace gases and aerosols in BB plumes creates analytical challenges in quantifying EFs, especially for semi-volatile and low-volatility organics, which are challenging to measure and identify but contribute significantly to secondary aerosol formation and 
photochemistry within the plume (Alvarado and Prinn, 2009; Alvarado et al., 2015; Ortega et al., 2013).

Plume rise is a description of how high the buoyant smoke plume rises above the fire and consequently the initial vertical distribution of trace gases and aerosols in the plume (Freitas et al., 2007). This is still a large area of uncertainty in BB models, typically using a generalised plume rise approach, which may include either homogenous mixing, prescribed fractions of emissions distributed according to mixing height, use of parametisations, and finally plume rise calculated according to atmospheric dynamics. A key driver of this uncertainty is the complexity of fire behaviour, resulting in high spatial and temporal variability in pollutant and heat release, which drives variability in plume rise behaviour, such as multiple updraft cores (Goodrick et al., 2013).

Transport and dilution in models is driven by meteorology, particularly wind speed and direction, wind shear and atmospheric stability. Meteorology has a large impact on the ability of models to simulate the timing and magnitude and even composition of BB plume impacts in both local- and regional-scale models (Lei et al., 2013; Luhar et al., 2008; Arnold et al., 2015). For example, too-high wind speeds can lead to modelled pollutant levels that are lower than observed (e.g. Lei et al., 2013), while small deviations in wind direction lead to large concentration differences between modelled and observed levels, particularly when modelling emissions of multiple spatially diverse fires (Luhar et al., 2008). Dilution of BB emissions in large grid boxes in global models may also lead to discrepancies between modelled and observed $\mathrm{NO}_{x}, \mathrm{O}_{3}$ and aerosols (Alvarado et al., 2009).

Finally, models use a variety of gas-phase and aerosolphase physical and chemical schemes, which vary in their ability to accurately represent chemical transformations, including formation of $\mathrm{O}_{3}$ and organic aerosol (Alvarado and Prinn, 2009; Alvarado et al., 2015). Validating and constraining chemical transformations in models requires high quality, high-time-resolution $\mathrm{BB}$ observations of a wide range of trace gas and aerosol species, including important but infrequently measured species such as $\mathrm{OH}$ and semi-volatile and low-volatility NMOCs. Field observations, whilst often temporally and spatially scarce, are particularly valuable because the processes and products of BB plume processing are dependent on long-range transport, cloud processing, varying meteorological conditions and heterogeneous reactions.

In this work we test the ability of CSIRO's high-resolution 3-D Eulerian grid chemical transport model (CTM) to reproduce $\mathrm{BB}$ plume observations of the Robbins Island fire reported in Lawson et al. (2015), with a focus on CO, BC and $\mathrm{O}_{3}$. We undertake sensitivity studies using varying emission factors associated with a low, medium and high modified combustion efficiency (MCE), which in turn changes the NMOC / $\mathrm{NO}_{x}$ ratio, in contrast to other sensitivity studies that typically scale emissions of all species by a constant factor (Pacifico et al., 2015; Lei et al., 2013). We also test sensitivity to meteorology by coupling the CTM with two different meteorological models, The Air Pollution Model (TAPM) and CSIRO's Conformal Cubic Atmospheric Model (CCAM). The fire and fixed observation sites (Cape Grim) were only $20 \mathrm{~km}$ apart, and so simulation of the plume strikes is a stringent test of TAPM and CCAM's ability to reproduce wind speed and direction. Plume rise and chemical mechanism are held constant. Finally, we use TAPM-CTM to separate the contribution of the Robbins Island fire emissions and urban emissions to the observed $\mathrm{O}_{3}$ enhancements at Cape Grim reported in Lawson et al. (2015) and to determine the age of the $\mathrm{O}_{3}$-enhanced air parcels.

\section{Methods}

\subsection{Fire and measurement details}

Details of the fire and measurements are given in Lawson et al. (2015). Briefly, BB plumes were measured at the Cape Grim Baseline Air Pollution Station during the 2006 Precursors to Particles campaign, when emissions from a fire on nearby Robbins Island impacted the station. Fire burned through native heathland and pasture grass on Robbins Island some $20 \mathrm{~km}$ to the east of Cape Grim for 2 weeks in February 2006. On two occasions an easterly wind advected the BB plume directly to the Cape Grim Station. The first plume strike (BB1) occurred from 02:00 to 06:00 (Australian eastern standard time - AEST) on 16 February, with light easterly winds of $3 \mathrm{~ms}^{-1}$, a temperature of $13^{\circ} \mathrm{C}$ and a relative humidity $(\mathrm{RH})$ of $96 \%$. The second, more prolonged plume strike (BB2) occurred from 23:00 on 23 February to 05:00 on 25 February, with strong easterly winds ranging from 10 to $16 \mathrm{~m} \mathrm{~s}^{-1}$, temperatures of $16-22^{\circ} \mathrm{C}$ and $\mathrm{RH}$ in the range of 75-95\%. Under a northerly wind direction, urban air from the city of Melbourne (population 4.2 million) some $300 \mathrm{~km}$ away is transported across the ocean (Bass Strait) to Cape Grim.

A wide variety of trace gas and aerosol measurements were made during the fire event (Lawson et al., 2015). In this work, measurements of black carbon (BC), carbon monoxide $(\mathrm{CO})$ and ozone $\left(\mathrm{O}_{3}\right)$ are compared with model output. BC measurements were made using an Aethalometer (Gras, 2007), CO measurements were made using an AGAGE gas chromatography system with a multi-detector (Krummel et al., 2007) and $\mathrm{O}_{3}$ measurements were made using a TECO analyser (Galbally et al., 2007). For further details see Lawson et al. (2015).

\subsection{Chemical transport models}

Simulations were undertaken with CSIRO's CTM, coupled offline with two meteorological models (see below). The CSIRO CTM is a three-dimensional Eulerian CTM with the capability of modelling the emission, transport, chemical transformation, wet and dry deposition of a coupled gas- and aerosol-phase atmospheric system. The CTM was initially 
developed for air quality forecasting (Cope et al., 2004) and has had extensive use with shipping emission simulations (Broome et al., 2016), urban air quality (Cope et al., 2014; Galbally et al., 2008), and biogenic (Emmerson et al., 2016) and biomass burning studies (Keywood et al., 2015; Meyer et al., 2008; Luhar et al., 2008).

The chemical transformation of gas-phase species was modelled using an extended version of the Carbon Bond 5 mechanism (Sarwar et al., 2008) with updated toluene chemistry (Sarwar et al., 2011). The mechanism was also extended to include the gas-phase precursors for secondary (gas and aqueous phase) inorganic and organic aerosols. Secondary inorganic aerosols were assumed to exist in thermodynamic equilibrium with gas-phase precursors and were modelled using the ISORROPIA-II model (Fountoukis and Nenes, 2007). Secondary organic aerosol was modelled using the volatility basis set (VBS) approach (Donahue et al., 2006). The VBS configuration is similar to that described in Tsimpidi et al. (2010). The production of S-VI in cloud water was modelled using the approach described in Seinfeld and Pandis (1998). The boundary concentrations in the models for different wind directions were informed by Cape Grim observations of atmospheric constituents during non-BB periods (Lawson et al., 2015). In this work the modelled elemental carbon (EC) output was considered equivalent to the $\mathrm{BC}$ measured with an Aethalometer at Cape Grim.

Horizontal diffusion is simulated according to equations detailed in Cope et al. (2009) according to the principles of Smagorinsky et al. (1963) and Hess (1989). Vertical diffusion is simulated according to equations detailed in Cope et al. (2009) according to the principles of Draxler and Hess (1997). Horizontal and vertical advection use the approach of Walcek et al. (2000).

\subsubsection{Meteorological models}

Prognostic meteorological modelling was used for the prediction of meteorological fields including wind velocity, temperature, water vapour mixing ratio and clouds, radiation, and turbulence. The meteorological fields force key components of the emissions and the chemical transport model. Two meteorological models were used in this work. CSIRO's TAPM (Hurley, 2008a, b), a limited area, nestable, threedimensional Eulerian numerical weather and air quality prediction system, and CSIRO's CCAM, a global stretched-grid atmospheric simulation model (McGregor, 2015, and references therein). The models represent two unique (and independent) approaches for generating the meteorological fields required by the CTM.

For CCAM, $20 \mathrm{~km}$ spaced simulations over Australia were used by the CTM (with the same grid spacing) to model large-scale processes on the continent, including the emission and transport of windblown dust, sea salt aerosol and smoke from wildfires. Note that the governing equations for TAPM do not enable this model to simulate spatial scales

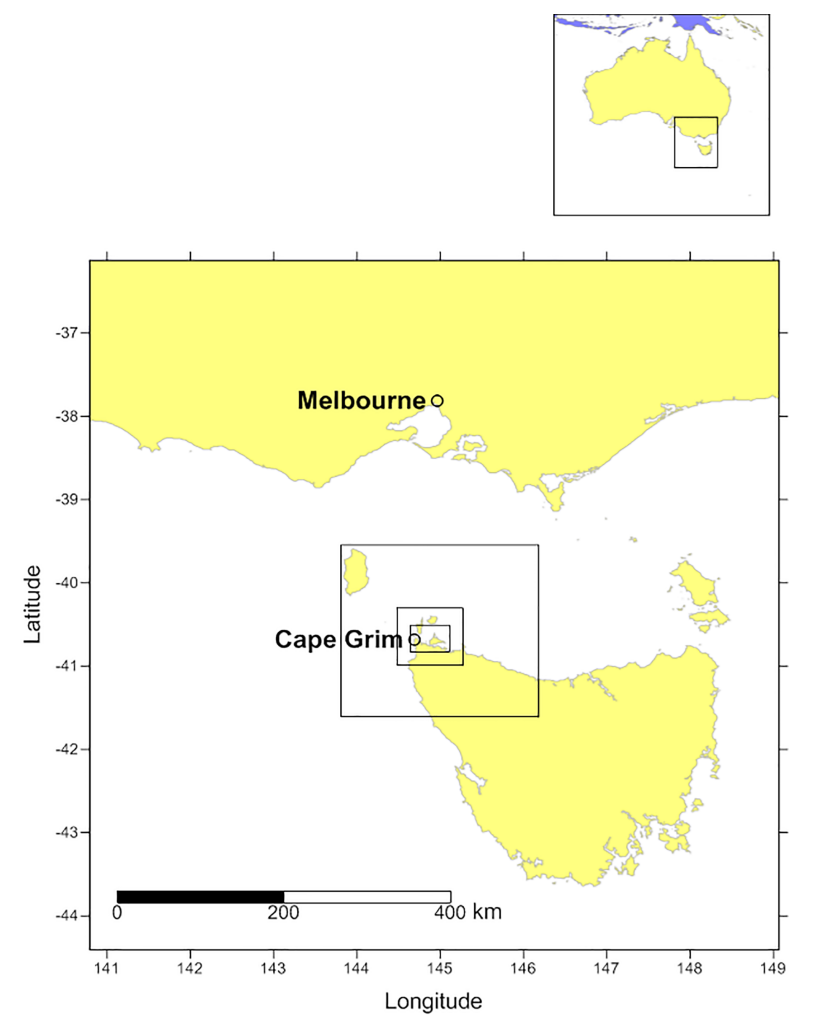

Figure 1. The five nested computational domains used in TAPMCTM and CCAM-CTM, which had cell spacings of 20, 12, 3, and $1 \mathrm{~km}$ and $400 \mathrm{~m}$.

greater than $1000 \mathrm{~km}$ in the horizontal and thus only the CCAM meteorology was available for the continental-scale simulations. TAPM and CCAM $12 \mathrm{~km}$ spaced simulations were then used to model the transport of the Melbourne plume to Cape Grim using the CTM (at $12 \mathrm{~km}$ grid spacing) with boundary conditions provided by the continental simulation. Nested grid simulations by the CTM at 3 and $1 \mathrm{~km}$ grid spacing utilised TAPM and CCAM meteorology simulated at matching grid spacing. The $1 \mathrm{~km}$ spaced meteorological fields were also used to drive a $400 \mathrm{~m}$ spaced CTM domain that encompassed Robbins Island and Cape Grim. This domain was included in the nested grid system because we wanted to better numerically resolve the spatial extent of the fire and the process of plume advection between Robbins Island and Cape Grim. Figure 1 shows the five nested computational domains used in TAPM-CTM and CCAM-CTM.

In this work the CTM coupled with the CCAM meteorological model is referred to as CCAM-CTM, while the CTM coupled with the TAPM meteorological model is referred to as TAPM-CTM. 


\subsubsection{Emission inventories}

\section{Anthropogenic emissions}

Anthropogenic emissions for Victoria were based on the work of Delaney et al. (2011). No anthropogenic emissions were included for Tasmania. The north-west section of Tasmania has limited habitation and is mainly farmland, and thus the influence of Tasmanian anthropogenic emissions on Cape Grim are expected to be negligible.

\section{Natural and biogenic emissions}

The modelling framework includes methodologies for estimating emissions of sea salt aerosol (Gong, 2003), emissions of windblown dust (Lu and Shao, 1999), gaseous and aerosol emissions from managed and unmanaged wild fires (Meyer et al., 2008), emissions of NMOCs from vegetation (Azzi et al., 2012), and emissions of nitric oxide and ammonia from vegetation and soils. Emissions from all but the wildfires are calculated inline in the CTM at each time step using the current meteorological fields. There were no other major fires burning in Victoria and Tasmania during the study period.

\section{Emissions - Robbins Island fire}

The area burnt by the fire was determined from hotspots from the Sentinel product (Geosciences Australia), which were derived from MODIS imagery. The hotspots were buffered to give polygon spots at a resolution of 400 ha spot $^{-1}$, then merged into a single polygon for each fire day (Meyer et al., 2008). The fire burnt 2000 ha over the 2 -week period, and the direction of fire spread was unknown. As such, the fire scar was divided up into $250 \mathrm{~m}$ grids and the hourly areas burnt were calculated using a normalised version of the McArthur Forest Fire Danger Index (FFDI) (Meyer et al., 2008). The models assumed that an equal proportion of each grid burned simultaneously over the 2 -week period. The fuel density used was estimated to be $18.7 \mathrm{tCha}^{-1}$, based on mean mass loads of coarse and fine fuels taken from the biogeochemical production model (VAST 1.2; Barrett, 2002) and converted into carbon mass (Meyer et al., 2008).

The hourly diurnal emissions of all gases and particles from the fire were calculated using the FFDI in which the presence of strong winds will result in faster fire spread and enhanced emissions, compared to periods of lower wind speeds. The effect of wind speed on the fire behaviour and emissions is particularly important during BB2 in which the winds ranged from 10 to $15 \mathrm{~m} \mathrm{~s}^{-1}$. This is evident from Fig. 2 in which hourly emission profiles based on an average diurnal FFDI calculated by Meyer et al. (2008) (which peaks early afternoon) is compared with profiles based on hourly FFDIs generated by TAPM and CCAM meteorology. It can be seen that the use of the dynamic FFDI approach during the BB2 period increases the base emissions by $70 \%$ for TAPM meteorology and by $45 \%$ for the CCAM meteorol- ogy. It is also notable that the use of the dynamic approach with TAPM meteorology leads to the peak emissions occurring overnight on 24 February, which is when the base emissions are at a minimum.

Three different sets of fire EFs, corresponding to low, medium and high $\mathrm{MCE}$, were used to test the sensitivity of the models, where $\mathrm{MCE}=\Delta \mathrm{CO}_{2} / \Delta \mathrm{CO}+\Delta \mathrm{CO}_{2}($ Ferek et al., 1998). We used published EFs of $\mathrm{CO}$ and $\mathrm{CO}_{2}$ from temperate forests (Akagi et al., 2011) to calculate a typical range of MCEs for temperate fires, including an average (best estimate) of 0.92 and a lower (0.89) and upper estimate (0.95). Fires with MCEs of approximately 0.90 consume biomass with approximately equal amounts of smouldering and flaming, while MCEs of 0.99 indicate complete flaming combustion (Akagi et al., 2011). Therefore, the calculated range of MCEs (0.89-0.95) corresponds to fires in which both smouldering and flaming occurs, with a tendency for more flaming combustion in the upper estimate (0.95) compared to a tendency for more smouldering in the lower estimate (0.89).

In previous smoke modelling work, CCAM-CTM and TAPM-CTM used savannah EFs from Andreae and Merlet (2001). However, as Robbins Island is in a temperate region, the Andreae and Merlet (2001) savannah EFs used in the models were adjusted to reflect temperate EFs based on the following methodology. Minimum, mean and maximum CO EFs for temperate forests from Agaki et al. (2011) were used for lower, best-estimate and upper MCEs. For all other species, savannah EFs (corresponding to an MCE of 0.94) were adjusted to EFs for the lower, best-estimate and upper MCEs using published relationships between MCE and EF (Meyer et al., 2012; Yokelson et al., 2007, 2003, 2011).

For example, to adjust the Andreae and Merlet (2001) savannah EFs (corresponding to an MCE of 0.94) to our temperate best-estimate EF (corresponding to an MCE of 0.92) the Andreae and Merlet (2001) NO EF was reduced by $30 \%$, the NMOC EFs were increased by $30 \%$, the BC EF was reduced by $30 \%$ and the OC EF was increased by $20 \%$. Table 1 gives EFs for the original savannah EF (Andreae and Merlet, 2001) and the adjusted EF used in this work. The $\mathrm{NO}_{x}$ / NMOC ratios used are also shown and vary by a factor of 3 between the low- and high-MCE scenarios, mainly driven by the variability in NO emissions with MCE. The EF calculated from observations for this fire are shown for comparison (Lawson et al., 2015).

We recognise that calculating EF in this way is approximate; however, the purpose of including a range of EFs was to explore the model's sensitivity to EF. While EFs were calculated for the Robbins Island fire for several species (Lawson et al., 2015), these are only available for a subset of species required by the CB05 chemical mechanism. The adjustment of the Andreae and Merlet (2001) savannah EFs to a lower MCE (0.89) resulted in good $( \pm 20 \%)$ agreement with the calculated EFs for $\mathrm{CO}, \mathrm{BC}$ and several NMOCs from Lawson et al. (2015), in which the MCE was calcu- 


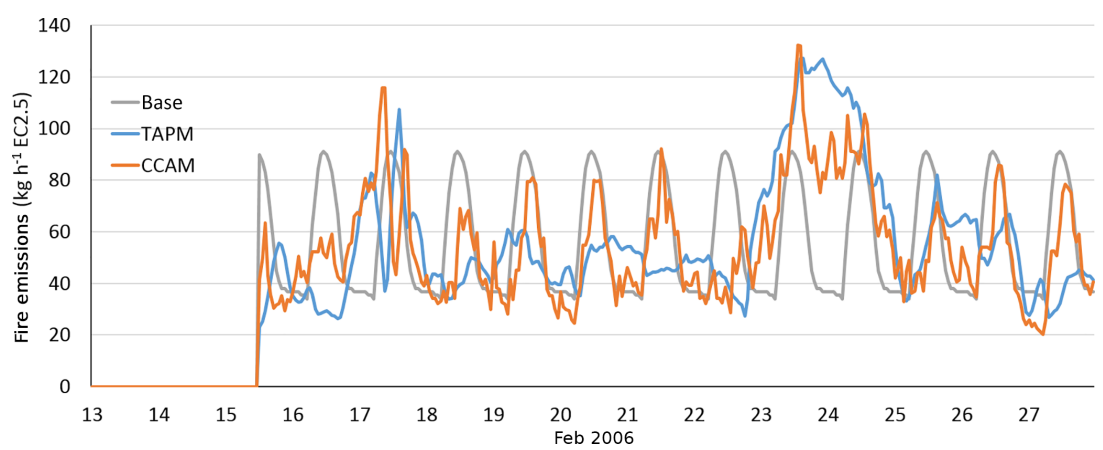

Figure 2. Base hourly diurnal emissions and emissions using the revised McArthur Forest Fire Danger Index (FFDI) generated using TAPM and CCAM meteorology.
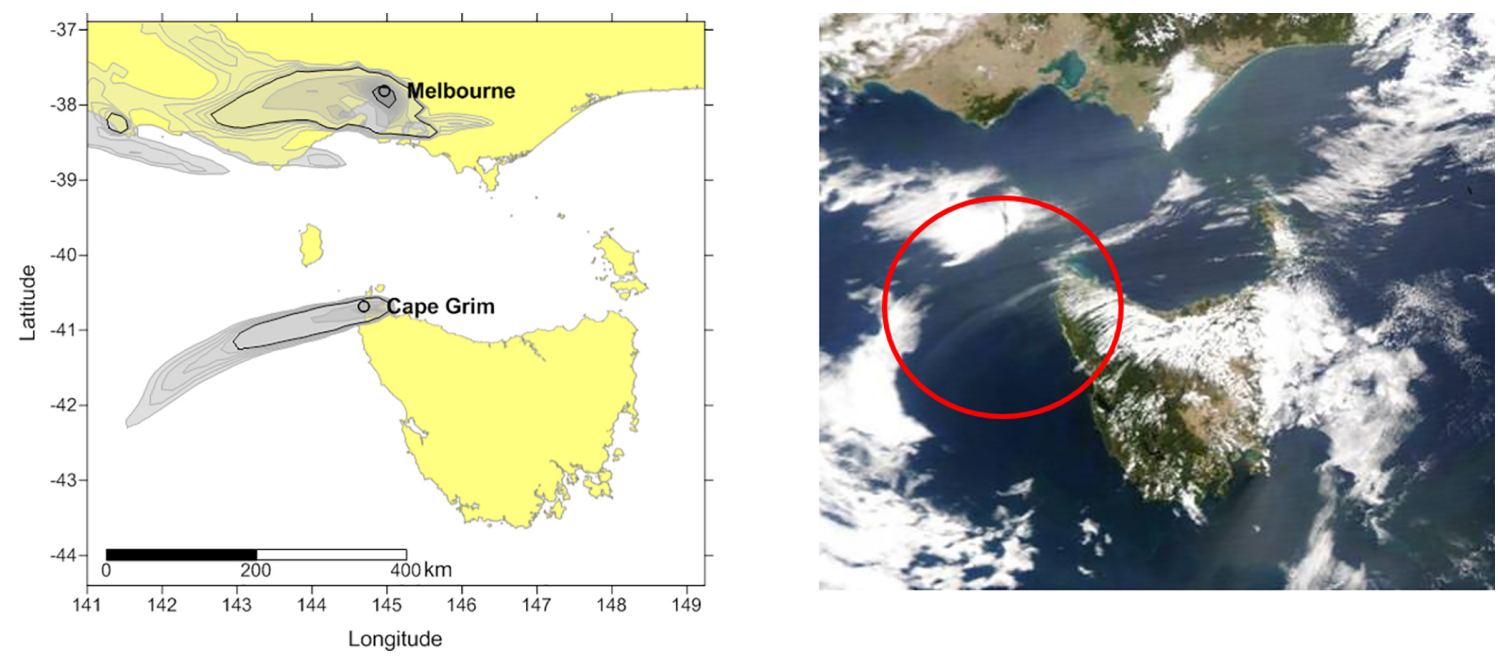

Figure 3. Model output of BC (left) on 23 February, with a MODIS True Color image of the same period.

lated as 0.88 . This provides confidence in using published relationships between MCE and EF to estimate EFs in this work.

With respect to plume rise, the Robbins Island fire was a relatively low-energy burn (Lawson et al., 2015), and as noted by Paugam et al. (2016), the smoke from such fires is largely contained within the planetary boundary layer (PBL). Given that ground-based images of the Robbins Island smoke plume support this hypothesis, in this work we adopted a simple approach of mixing the emitted smoke uniformly into the model's layers contained within the PBL. The plume was well mixed between the maximum of the PBL height and $200 \mathrm{~m}$ above the ground, with the latter included to account for some vertical mixing of the buoyant smoke plume even under conditions of very low PBL height. The high wind speeds, particularly during the second BB event, also suggest that the plume was not likely to be sufficiently buoyant to penetrate the PBL.

\section{Results and discussion}

\subsection{Modelling sensitivity study}

The ability of the models to reproduce the two plume strikes (BB1 and BB2; described in Lawson et al., 2015) was tested. The period examined was 13 February 2006 to 28 February 2006. The sensitivity of the models to meteorology, EFs and spatial variability was also investigated and is discussed below. Observational and model data shown are hourly averages. Table 2 summarises the main findings of the model sensitivity study. A MODIS True Color Aqua image of the Robbins Island fire plume is shown in Fig. 3 from 23 February 2006, with the modelled plume during the same period.

\subsubsection{Sensitivity of modelled BB species to meteorology}

Qualitative and quantitative assessments of model performance for meteorological parameters were undertaken for both TAPM and CCAM. Hourly observed and modelled winds, temperature, humidity and PBL are compared and discussed in the Supplement (Figs. S2-S8). Briefly, both TAPM 
Table 1. EF used in model sensitivity studies, corresponding to low $(\mathrm{MCE}=0.89)$, medium $(\mathrm{MCE}=0.92)$ and high $(\mathrm{MCE}=0.95) \mathrm{MCEs}$. A subset of the total species included in the CB05 lumped chemical mechanism are shown. Also shown are savannah EFs from Andreae and Merlet (2001) (A\&M) and EFs calculated from BB2 in previous work (Lawson et al., 2015). NO: nitric oxide, CO: carbon monoxide, PAR: paraffin carbon bond, OLE: terminal olefin carbon bond, TOL: toluene and other monoalkyl aromatics, XYL: xylene and other polyalkyl aromatics, BNZ: benzene, FORM: formaldehyde, ALD2: acetaldehyde, EC: elemental carbon $<10 \mu$ m and OC: primary organic carbon $<$ $10 \mu \mathrm{m}$.

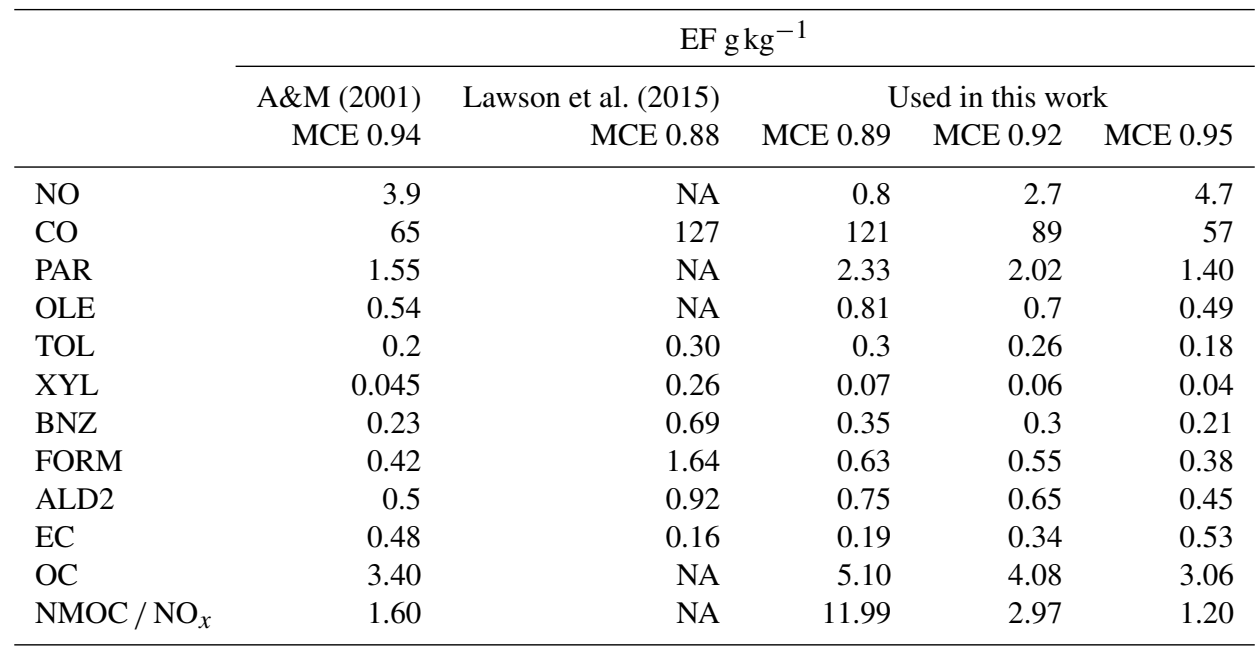

NA: not available.

Table 2. Summary of sensitivity study results, including meteorology, emission factors and spatial variability.

\begin{tabular}{llll}
\hline $\begin{array}{l}\text { Sensitivity } \\
\text { study }\end{array}$ & Species & $\begin{array}{l}\text { TAPM-CTM } \\
\text { simulation }\end{array}$ & $\begin{array}{l}\text { CCAM-CTM } \\
\text { simulation }\end{array}$ \\
\hline $\begin{array}{l}\text { Meteorology } \\
\text { (Sect. 3.1.1) }\end{array}$ & BC and CO & $\begin{array}{l}\text { BB1 plume strike }+3 \mathrm{~h} \\
\text { Duration 12 } \mathrm{h}(\text { actual } 5 \mathrm{~h})\end{array}$ & $\begin{array}{l}\text { BB1 plume strike }-12 \mathrm{~h} \\
\text { Duration 36 } \mathrm{h} \text { intermittent } \\
\text { (actual 5h) }\end{array}$ \\
& & $\begin{array}{l}\text { BB2 plume strike }-26 \mathrm{~h} \\
\text { Duration 50 } \mathrm{h}(\text { actual 29h) }\end{array}$ & $\begin{array}{l}\text { BB2 plume strike }-26 \mathrm{~h} \\
\text { Duration 57 } \mathrm{h}(\text { actual } 29 \mathrm{~h})\end{array}$ \\
& &
\end{tabular}

Comments/drivers of model outputs

Duration 50h (actual 29h)

Duration 57 h (actual 29h)

\begin{tabular}{|c|c|c|c|c|}
\hline & $\mathrm{O}_{3}$ & $\begin{array}{l}\text { Four } \mathrm{O}_{3} \text { peaks simulated } \\
\text { (two observed, two not) }\end{array}$ & $\begin{array}{l}\text { One } \mathrm{O}_{3} \text { peak simulated } \\
\text { (observed) }\end{array}$ & $\begin{array}{l}\text { Differences in simulated wind speed } \\
\text { and direction (and EF - see below) }\end{array}$ \\
\hline \multirow[t]{2}{*}{$\begin{array}{l}\text { Emission } \\
\text { factors } \\
\text { (Sect. 3.1.2) }\end{array}$} & $\mathrm{BC}$ and $\mathrm{CO}$ & $\begin{array}{l}\text { BC peak magnitude varies } \\
\text { by factor } 3 \text {, CO factor } 2 \\
\text { with different EF runs }\end{array}$ & As for TAPM -CTM & $\begin{array}{l}\text { Concentrations vary according to EF in- } \\
\text { put ratios. }\end{array}$ \\
\hline & $\mathrm{O}_{3}$ & $\begin{array}{l}\text { Two peaks with high EF } \\
\text { sensitivity, two peaks with } \\
\text { no EF sensitivity }\end{array}$ & $\begin{array}{l}\text { One peak with no EF sensi- } \\
\text { tivity }\end{array}$ & $\begin{array}{l}\text { Different } \mathrm{NMOC} / \mathrm{NO}_{x} \text { emission ratios } \\
\text { (varies with } \mathrm{MCE} \text { ) drive destruction or } \\
\text { production of } \mathrm{O}_{3} \text { in fire-related peaks. } \\
\text { MCE } 0.89 \text { TAPM-CTM simulation } \\
\text { gives best agreement with observations }\end{array}$ \\
\hline \multirow[t]{2}{*}{$\begin{array}{l}\text { Spatial } \\
\text { variability } \\
\text { (Sect. 3.1.3) }\end{array}$} & $\mathrm{CO}$ & $\begin{array}{l}\text { Differences of up to } \\
>500 \text { ppb in grid points } \\
1 \mathrm{~km} \text { apart (BB2) }\end{array}$ & NA & Narrow BB plume \\
\hline & $\mathrm{O}_{3}$ & $\begin{array}{l}\text { Differences of up to } 15 \mathrm{ppb} \\
\text { in grid points } 1 \mathrm{~km} \text { apart } \\
\text { (BB1) }\end{array}$ & $\mathrm{n} / \mathrm{a}$ & $\begin{array}{l}\text { Narrow ozone plume generated down- } \\
\text { wind of fire }\end{array}$ \\
\hline
\end{tabular}



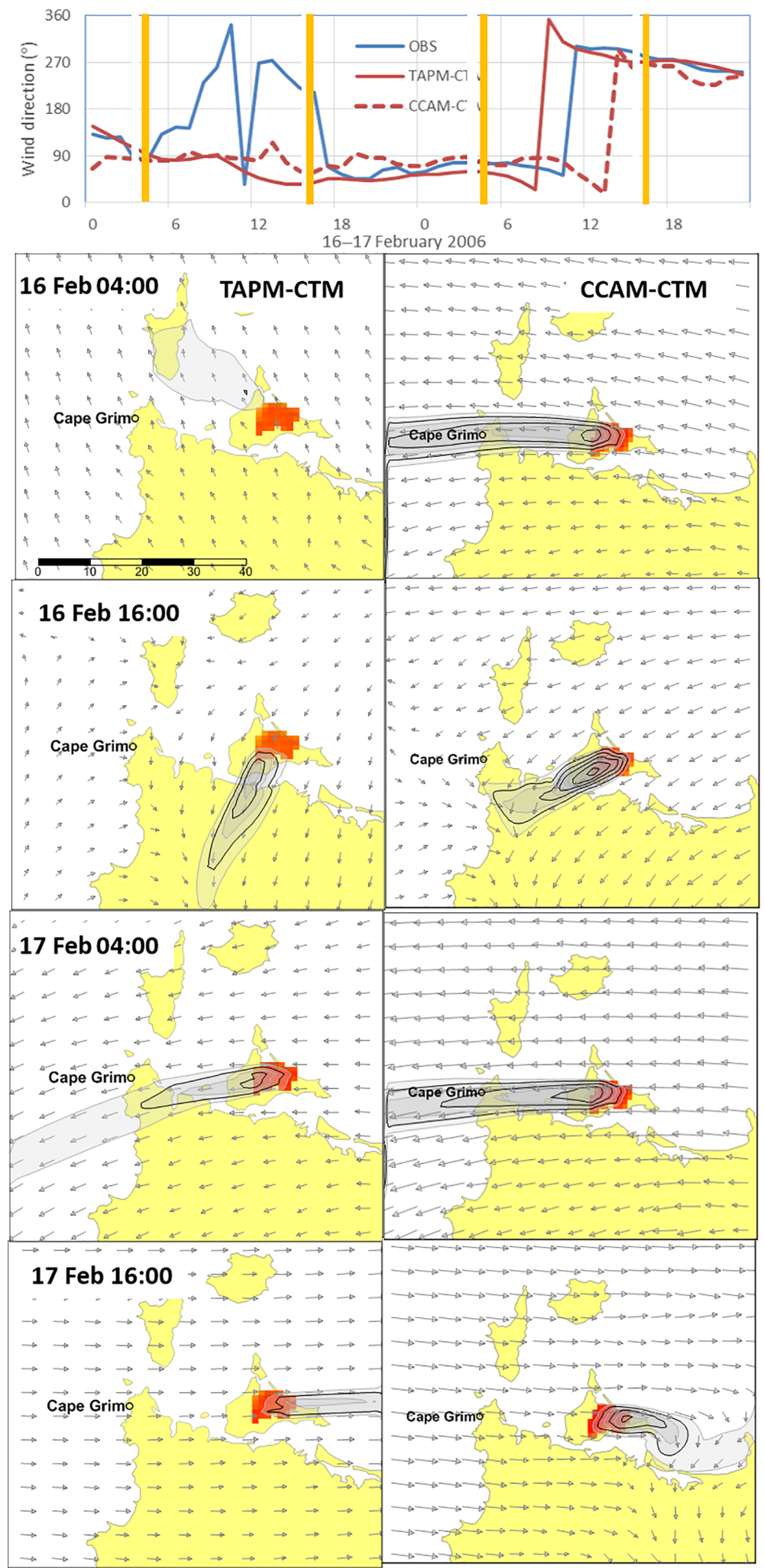

Figure 4. Model concentration isopleth of BC for TAPM-CTM (left panels) and CCAM-CTM (right panels). Panels show $12 \mathrm{~h}$ time intervals during BB1, including the BB plume intermittently striking Cape Grim, followed by the change in plume direction with wind direction change. Arrows are wind vectors. The time series of observed and modelled wind direction for BB1 are shown above with golden bands highlighting the periods corresponding to the panels. 


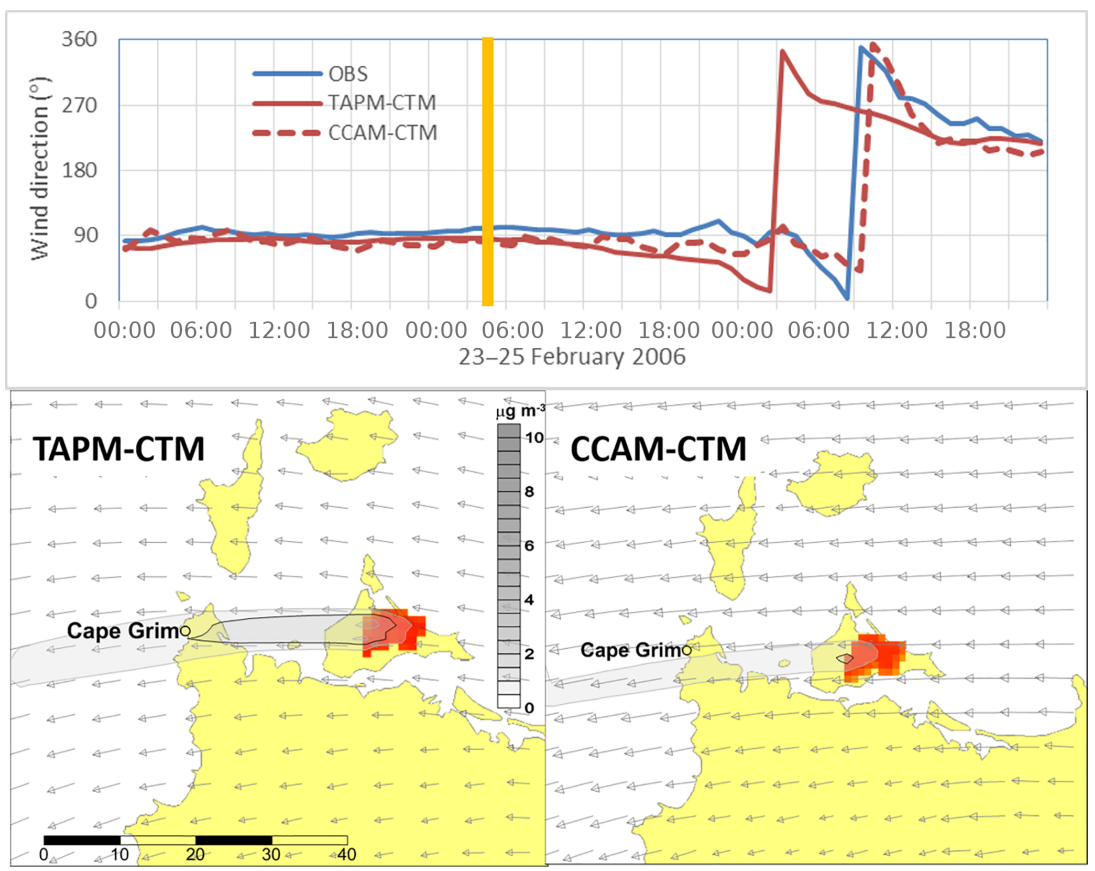

Figure 5. Model concentration isopleth of BC for TAPM-CTM and CCAM-CTM at 05:00 on 24 February during BB2. Arrows are wind vectors. The time series of observed and modelled wind direction for BB2 is shown above with a golden band highlighting the period corresponding to the panels.

and CCAM demonstrated reasonable skill in modelling the meteorological conditions, with the TAPM simulations being slightly better than the CCAM simulations with respect to the low-level wind, temperatures and RH and CCAM simulations being slightly better in terms of PBL height.

\section{Primary species - CO and BC}

Figures 4 and 5 show concentration isopleths for BC generated by TAPM-CTM and CCAM-CTM for BB1 and BB2 respectively. The simulated and observed time series concentrations of $\mathrm{CO}$ and $\mathrm{BC}$ for the two different models (TAPMCTM and CCAM-CTM) and for three different sets of EFs (discussed in Sect. 3.1.2) are shown in Fig. 6. TAPM-CTM and CCAM-CTM both reproduce the observed plume strikes (BB1 and BB2). The impact of meteorology on the plume strike timing and duration is discussed below.

Both models overestimate the duration of BB1 and are a few hours out in the timing of the plume strike. TAPMCTM predicts that the timing of $\mathrm{BB} 1$ is $3 \mathrm{~h}$ later than occurred (BC data) and predicts that BB1persists for $12 \mathrm{~h}(\mathrm{ob}-$ served duration $5 \mathrm{~h}$ ). CCAM-CTM predicts that BB1 occurs $12 \mathrm{~h}$ prior to the observed plume strike and predicts that the plume intermittently sweeps across Cape Grim for up to $36 \mathrm{~h}$ (Fig. 4). Both models indicate that the plume is narrow and meandering.
Both models overestimate the duration of BB2 and simulate the plume strike occurring earlier than observed. TAPMCTM predicts that BB2 is $26 \mathrm{~h}$ earlier than observed and that BB2 persists for $50 \mathrm{~h}$ (observed duration $29 \mathrm{~h}$ ). CCAM-CTM predicts that $\mathrm{BB} 2$ is $26 \mathrm{~h}$ earlier than observed and that $\mathrm{BB} 2$ persists for $57 \mathrm{~h}$. It should be noted that there is a brief observed enhancement of BB species that corresponds with the beginning of the modelled BB2 plume strike, some $24 \mathrm{~h}$ prior to the prolonged observed event. This was likely due to the edge of the plume impacting the station briefly.

In both observed BB1 and BB2 the plume strike at Cape Grim occurred just prior to a wind direction change from easterly (fire direction) to south-westerly. The timing of the wind direction change in the models is therefore crucial to correctly predicting plume strike time and duration. In BB1 CCAM predicts an earlier wind direction change with higher wind speeds, which advects the plume directly over Cape Grim, while TAPM predicts a later wind change, lower wind speeds and advection of only the edge of the plume over Cape Grim. The higher concentrations $\mathrm{CO}$ and $\mathrm{BC}$ in $\mathrm{BB} 1$ predicted by CCAM-CTM are likely due to the direct advection of the plume over the site compared to only the plume edge in TAPM-CTM.

In BB2, both TAPM-CTM and CCAM-CTM predict direct strikes of the Robbins Island smoke plume on Cape Grim because the wind direction is modelled to be predominantly easterly for the duration of the event (Fig. 5). Both models simulate some backing and veering of the wind direction 
for the duration of BB2 due to gravity wave processes that lead to intermittent strikes on Cape Grim as the Robbins Island smoke plume sweeps to the north and south of Cape Grim. The gravity wave oscillations are more pronounced in CCAM-CTM than TAPM-CTM (and thus the plume strikes are more pronounced from the former) due to differences in how the models are coupled to large-scale synoptic forcing. The event is eventually curtailed by the passage of a southwesterly change.

Figure 5 shows that TAPM-CTM predicts the onset of the change to occur about $6 \mathrm{~h}$ ahead of the observed change and thus the $\mathrm{BB} 2$ event ends too early for this meteorological simulation. CCAM-CTM models the south-westerly change to occur $1 \mathrm{~h}$ after observed, leading to the modelled BB2 event extending beyond the observed duration for this meteorological simulation.

Differences in the magnitude of the modelled $\mathrm{CO}$ and $\mathrm{BC}$ peaks for TAPM-CTM and CCAM-CTM have two principal causes: (a) the coupling of the smoke emissions to the TAPM and CCAM meteorology via the FFDI scaling leads to approximately $20 \%$ higher emissions in the case of the TAPM-CTM simulations; (b) the CCAM wind speeds are 20-50\% higher than the TAPM wind speeds during BB2, which in combination with the emission differences, leads to TAPM-CTM generating near-surface smoke concentrations that are up to $80 \%$ higher than CCAM-CTM. Mixing depth can also play an important role in plume dispersion; however, the PBL heights generated by both models are similar and generally low during BB2 due to the easterly wind direction and the mainly maritime upwind fetch.

\section{Secondary species $-\mathrm{O}_{3}$}

Figure $6 \mathrm{e}$ and $\mathrm{f}$ show the simulated and actual $\mathrm{O}_{3}$ concentration time series for TAPM-CTM and CCAM-CTM for three different sets of EFs (discussed in Sect. 3.1.2). The two observed $\mathrm{O}_{3}$ peaks that followed $\mathrm{BB} 1$ and $\mathrm{BB} 2$ can clearly be seen in the time series of observations. Figure 7 shows the TAPM-CTM and CCAM-CTM concentration isopleths of $\mathrm{O}_{3}$ enhancement downwind of the fire during BB1 at 11:00 and 13:00 on 16 February.

Again the simulated meteorology has a major impact on the ability of the models to reproduce the magnitude and timing of the observed $\mathrm{O}_{3}$ peaks. TAPM-CTM reproduces the major $\mathrm{O}_{3}$ peak observed following $\mathrm{BB} 2$ and captures part of the $\mathrm{O}_{3}$ peak following $\mathrm{BB} 1$. For the peak following BB1 it underpredicts the peak duration and fails to capture the subsequent observed peaks on 18 and 19 February. TAPMCTM also shows two additional $\mathrm{O}_{3}$ peaks, which were not observed, about $24 \mathrm{~h}$ prior to the BB1 and BB2 peaks. The magnitude of these additional peaks shows a strong dependency on the EF, suggesting an influence of fire emissions. This is discussed further below and in Sect. 3.2.1. Compared to TAPM-CTM, CCAM-CTM predicts fewer distinct peaks of ozone above the background (where background is 15-
$17 \mathrm{ppb}$ ) throughout the entire period. Both TAPM-CTM and CCAM-CTM show depletion of $\mathrm{O}_{3}$ below background levels, which was not observed, and this is discussed further in Sect. 3.1.2.

Figure 7 shows that there are differences in wind fields between TAPM-CTM and CCAM-CTM as well as different simulated concentrations of $\mathrm{O}_{3}$ generated from the fire. This is discussed further in Sect. 3.1.2. To summarise, the impact of using two different meteorological models for a primary species such as $\mathrm{BC}$ was to vary the modelled time of impact of the BB1 plume strike by up to $15 \mathrm{~h}$ (CCAM-CTM $-12 \mathrm{~h}$ and TAPM-CTM $+3 \mathrm{~h}$, with actual plume strike time $=0 \mathrm{~h}$ ) and to vary the plume duration between 12 and $36 \mathrm{~h}$ (actual duration $5 \mathrm{~h}$ ). For BB2, different meteorological models predicted the same impact time (TAPM-CTM and CCAMCTM both $-26 \mathrm{~h}$, with the actual plume strike time $=0 \mathrm{~h}$ ) and showed the plume duration to vary between 47 and $60 \mathrm{~h}$ (actual duration $29 \mathrm{~h}$ ).

For $\mathrm{O}_{3}$, the use of different meteorological models led to one model (TAPM-CTM) reproducing both observed peaks plus two additional peaks, while the other model (CCAMCTM) captured only one defined $\mathrm{O}_{3}$ peak over the time series of 2 weeks.

\subsubsection{Sensitivity of modelled BB species to emission factors}

\section{Primary species - CO and BC}

Figure 6a-d show the simulated and observed concentrations of $\mathrm{BC}$ and $\mathrm{CO}$ for $\mathrm{MCE}=0.89, \mathrm{MCE}=0.92$ and $\mathrm{MCE}=$ 0.95 (see Sect. 2.2.2). Because $\mathrm{CO}$ has a negative relationship with $\mathrm{MCE}$, and $\mathrm{BC}$ has a positive relationship with $\mathrm{MCE}$, the modelled $\mathrm{BC}$ concentrations are highest for model runs using the highest MCE, while the modelled $\mathrm{CO}$ concentrations are highest for model runs using the lowest MCE (Fig. 6).

Changing the EF from low to high MCE varies the modelled BC concentrations during BB1 and BB2 by a factor of $\sim 3$ for $\mathrm{BC}$ and a factor of $\sim 2$ for $\mathrm{CO}$ and increases the $\mathrm{EF}$ ratio of $\mathrm{BC} / \mathrm{CO}$ by a factor of $\sim 6$, in proportion to the difference in $\mathrm{EF}$ input to the models.

Quantile-quantile plots of observed and modelled ratios of $\mathrm{BC} / \mathrm{CO}$ during $\mathrm{BB} 1$ and $\mathrm{BB} 2$ for the different $\mathrm{EF}$ scenarios are shown in Fig. 8. BC / $\mathrm{CO}$ ratios were used to minimise uncertainty resulting from errors in modelling transport and dilution (and mixing height), thus enabling a focus on the impact of EF variability. A period incorporating both the modelled and observed BB1 and BB2 was used for the analysis. The TAPM-CTM simulation with $\mathrm{MCE}=0.89$ performed best, with greater than $60 \%$ of the model percentiles falling within a factor of 2 of the observed. The CCAM-CTM simulation with $\mathrm{MCE}=0.89$ was the second best performer with $50 \%$ of the modelled percentiles falling within a factor of 2 of the observed. Overestimates of the EC/CO ratio by up to 

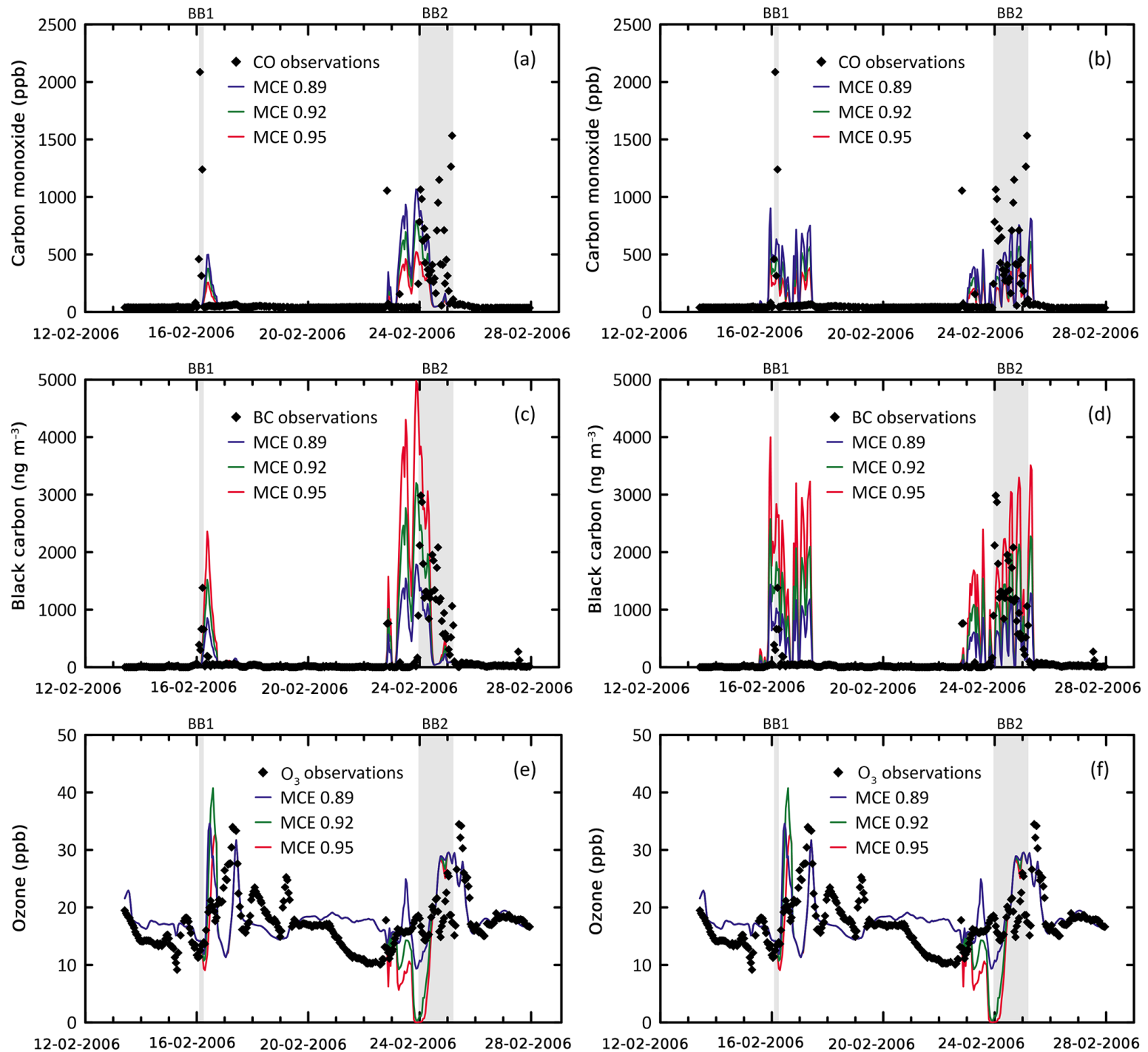

Figure 6. Simulated CO using (a) TAPM-CTM and (b) CCAM-CTM, simulated BC using (c) TAPM-CTM and (d) CCAM-CTM, and simulated $\mathrm{O}_{3}$ using (e) TAPM-CTM and (f) CCAM-CTM. Coloured lines represent different MCE EF simulations; black symbols are observations.

a factor of 8 occur for some percentiles for the $\mathrm{MCE}=0.95$ scenarios, while the scenarios with no fire significantly underestimated the observed ratio. Plots of mean fractional bias and mean fractional error (Figs. S11 and S12) show that the TAPM-CTM simulation with MCE $=0.89$ has the smallest bias and error, followed by the CCAM-CTM simulation with $\mathrm{MCE}=0.89$. As discussed previously, there is uncertainty in the derivation of $\mathrm{EF}$ as a function of MCE, as this was based on relationships from a small number of studies. Nevertheless, the percentile, bias and error analysis indicate that using EFs corresponding to an MCE of 0.89 gives the best agreement with the observations for the $\mathrm{BC} / \mathrm{CO}$ ratio. This is in agreement with the calculated MCE of 0.88 for this fire (Lawson et al., 2015)

\section{Secondary species $-\mathrm{O}_{3}$}

For secondary species such as $\mathrm{O}_{3}$ (Fig. 6e and f), the relationship between EF precursor gases and model output is more complex than for primary species such as $\mathrm{CO}$ and $\mathrm{BC}$ because the balance between $\mathrm{O}_{3}$ formation and destruction is dependent on the degree of dilution of the $\mathrm{BB}$ emissions and also factors such as the NMOC composition and the $\mathrm{NMOC} / \mathrm{NO}_{x}$ ratio.

TAPM-CTM (Fig. 6e) reproduces the magnitude of both observed peaks following BB1 and BB2 (BB1 maximum observed $=33 \mathrm{ppb}$, modelled $=31 \mathrm{ppb}$; BB2 maximum observed $=34 \mathrm{ppb}$, modelled $=30 \mathrm{ppb}$ ). Interestingly, the magnitude of $\mathrm{O}_{3}$ for these two peaks is the same for different EF inputs of $\mathrm{O}_{3}$ precursors from the Robbins Island fire, sug- 

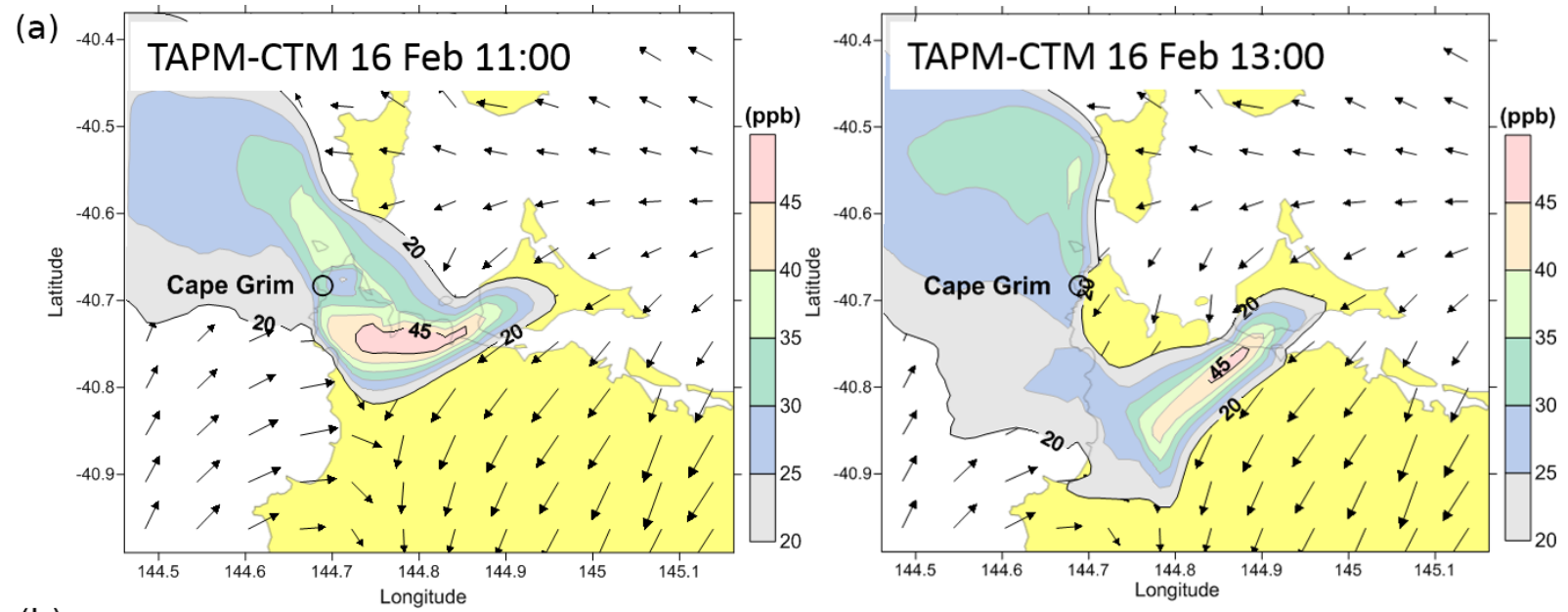

(b)
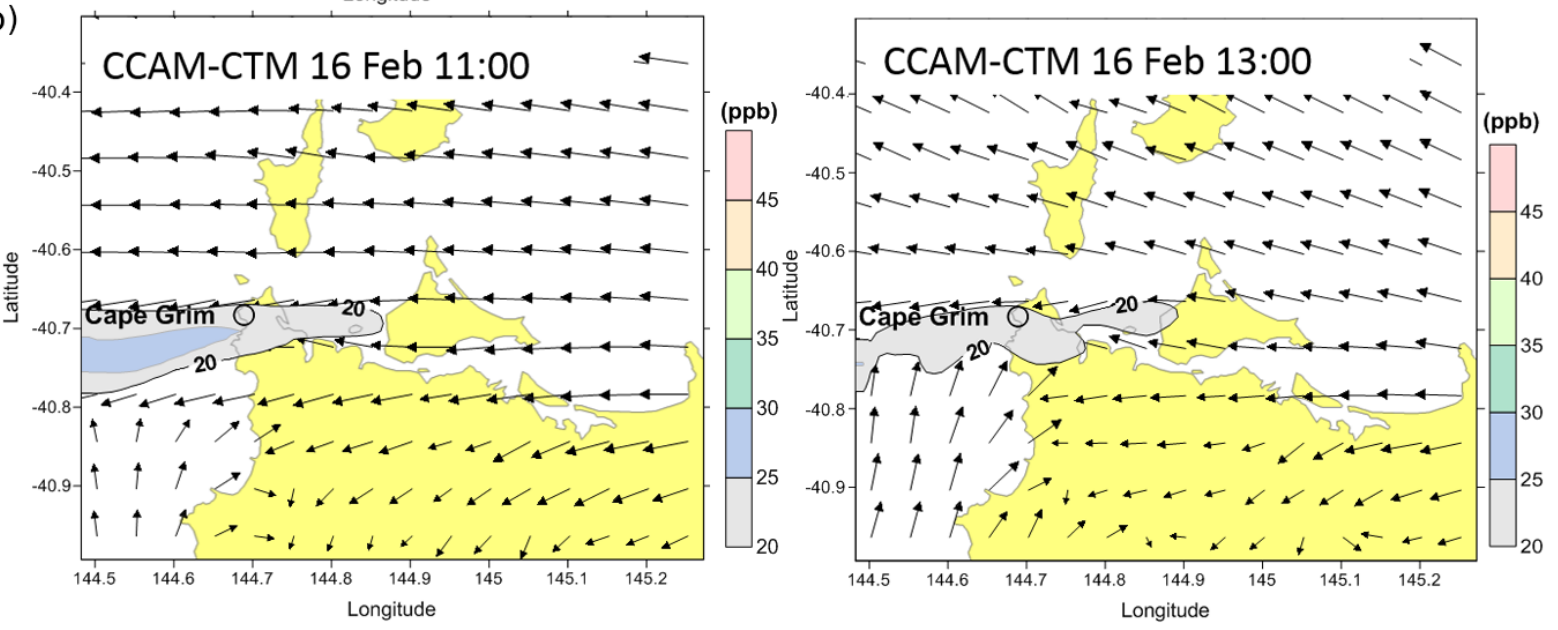

Figure 7. Model concentration isopleth showing $\mathrm{O}_{3}$ enhancement downwind of the fire during BB1 at 11:00 and 13:00 on 16 February for (a) TAPM-CTM and (b) CCAM-CTM. The spatially variable plume and complex wind fields are shown. Arrows are wind vectors.

gesting that the $\mathrm{BB}$ emissions are not responsible for these enhancements as demonstrated in Sect. 3.2. In contrast, the two additional peaks modelled but not seen in the observations are heavily dependent on the input EF. For the first additional modelled peak, which was predicted at the time of BB1 observations on 16 February, all EF scenarios result in an $\mathrm{O}_{3}$ peak, with the $\mathrm{MCE}=0.92$ model scenario resulting in the highest predicted $\mathrm{O}_{3}$. For the second additional modelled peak just prior to the BB2 observations on 23 February, only the $\mathrm{MCE}=0.89$ scenario results in net $\mathrm{O}_{3}$ production, while $\mathrm{MCE}=0.92$ and $\mathrm{MCE}=0.95$ scenarios lead to net $\mathrm{O}_{3}$ destruction.

This differing response to EF for the TAPM-CTM runs suggests the importance of the $\mathrm{NO} E F$ for $\mathrm{O}_{3}$ production in BB plumes. Unfortunately, there were no oxides of nitrogen measurements made during the fire to test the models. For the first simulated additional peak prior to BB1, while the medium NO EF $(\mathrm{MCE}=0.92)$ resulted in the highest $\mathrm{O}_{3}$ peak (with corresponding $\mathrm{NO}$ of $3.7 \mathrm{ppb}$ and $\mathrm{NO}_{2}$ of $4.5 \mathrm{ppb}$ ), the lower NO EF in the 0.89 MCE run perhaps indi- cates that insufficient $\mathrm{NO}$ was present to drive $\mathrm{O}_{3}$ production (corresponding $\mathrm{NO}$ of $0.5 \mathrm{ppb}$ and $\mathrm{NO}_{2}$ of $1.5 \mathrm{ppb}$ ), which is in line with studies that have shown that BB plumes are generally $\mathrm{NO}_{x}$ limited (Akagi et al., 2013; Jaffe and Wigder, 2012; Wigder et al., 2013). Conversely, the highest input $\mathrm{NO} E F(\mathrm{MCE}=0.95)$ led to net destruction of $\mathrm{O}_{3}(\mathrm{NO}$ of $9 \mathrm{ppb}, \mathrm{NO}_{2}$ of $7 \mathrm{ppb}$ ), which is due to titration of $\mathrm{O}_{3}$ with the larger amounts of $\mathrm{NO}$ emitted from the fire in these runs as indicated by excess $\mathrm{NO}\left(\mathrm{NO} / \mathrm{NO}_{2}\right.$ ratio $\left.>1\right)$ at Cape Grim (where NO has a positive relationship with MCE). For the second additional peak prior to BB2, only the lowest $\mathrm{NO} E F$ run $(\mathrm{MCE}=0.89)$ resulted in net production of $\mathrm{O}_{3}$ (NO of $1.5 \mathrm{ppb}, \mathrm{NO}_{2}$ of $2.6 \mathrm{ppb}$ ). In the medium- and highMCE runs, the background $\mathrm{O}_{3}$ concentration is completely titrated $(0 \mathrm{ppb})$, with $\mathrm{NO}$ concentrations of 10 and $20 \mathrm{ppb}$ and $\mathrm{NO} / \mathrm{NO}_{2}$ ratios of 1.3 and 2.6 respectively.

In contrast, the CCAM-CTM model (Fig. 6f) simulations reproduce only the first observed $\mathrm{O}_{3}$ peak associated with BB1 $($ modelled $=27 \mathrm{ppb}$, measured $=34 \mathrm{ppb}$ ). This modelled $\mathrm{O}_{3}$ peak does not show an influence of MCE on $\mathrm{O}_{3}$ con- 


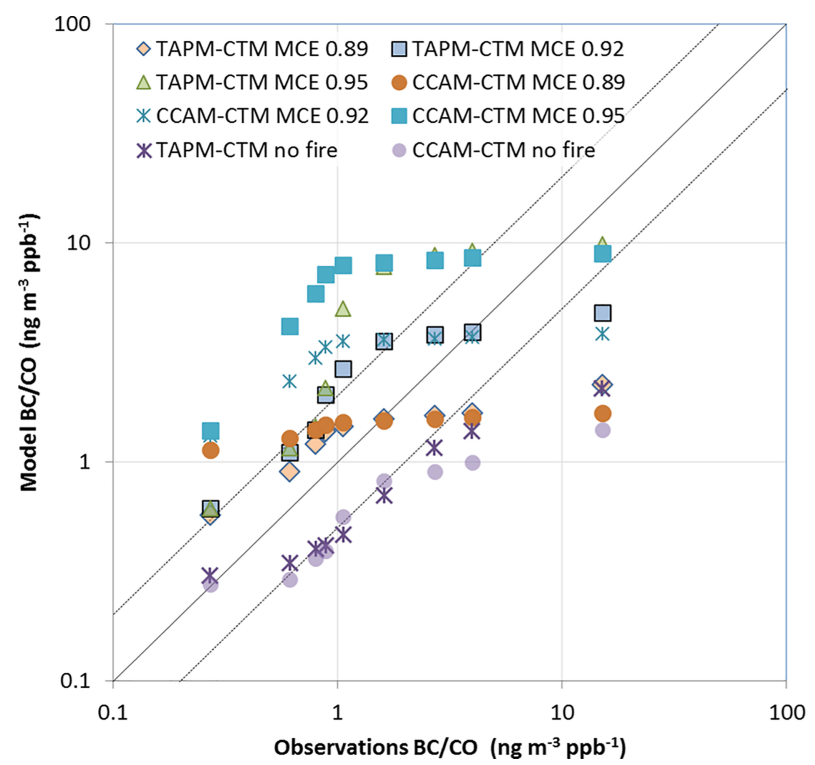

Figure 8. Quantile-quantile plots of observed and modelled BC / CO ratios for the TAPM-CTM and CCAM-CTM simulations. For each scenario, the model-data pairs correspond to the following percentiles: $0.2,0.3,0.4,0.5,0.6,0.7,0.8,0.9$ and 1 . Note the log scale on both axes. The solid line is $1: 1$ and dotted lines show performance within a factor of 2 .

centration, in agreement with TAPM, again suggesting no influence from fire emissions as later demonstrated in Sect. 3.2. The CCAM model runs also show significant titration of $\mathrm{O}_{3}$ during BB1 and BB2 for the medium- and high-MCE model runs, with $\sim 24$ and $\sim 48 \mathrm{~h}$ of significant $\mathrm{O}_{3}$ depletion below background concentrations being modelled for each event, which was not observed.

Quantile-quantile plots of modelled and observed concentrations of $\mathrm{O}_{3}$ for all EF scenarios are shown in Figs. 9 and S13. Model performance was assessed for both the BB and the background periods in order to test the ability of the models to reproduce $\mathrm{O}_{3}$ from both the fire and other sources, including urban sources. The modelled $\mathrm{O}_{3}$ concentrations from the TAPM-CTM simulation with MCE $=0.89$ are close to the $1: 1$ line with observations for all of the sampled percentiles and demonstrate that this scenario is in best agreement with observations. As stated previously, it is also in agreement with the calculated MCE of 0.88 for BB2 (Lawson et al., 2015). Ozone titration, which was not observed, in the $\mathrm{MCE}=0.92$ and $\mathrm{MCE}=0.95$ scenarios is visible as a significant deviation from the $1: 1$ line in Fig. 9. With the exception of these titration events, all of the sampled model concentration percentiles fall well within a factor of 2 of the observations. Plots of mean fractional error and mean fractional bias (Figs. S14 and S15) show that the error and bias are very low for all runs and fall within performance guidelines.

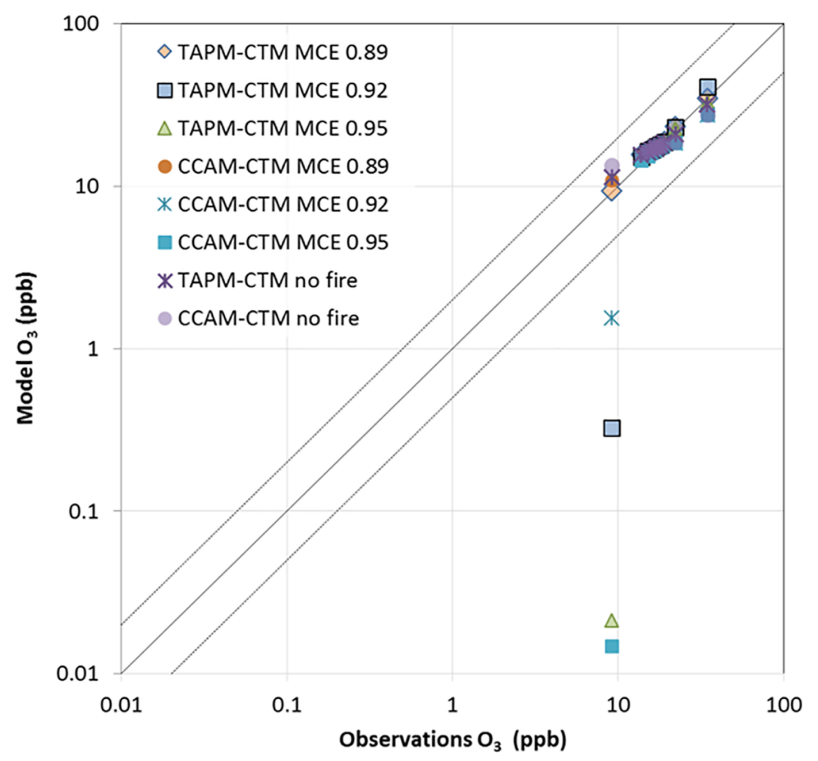

Figure 9. Quantile-quantile plots of observed and modelled $\mathrm{O}_{3}$ for the TAPM-CTM and CCAM-CTM simulations. For each scenario, the model-data pairs correspond to the following percentiles: 0.2 , $0.3,0.4,0.5,0.6,0.7,0.8,0.9$ and 1 . Note the log scale on both axes. The solid line is $1: 1$ and dotted lines show performance within a factor of 2 .

The different EF scenarios presented here suggest that varying model EFs have a major impact on whether the models simulate production or destruction of $\mathrm{O}_{3}$, particularly important at a receptor site in close proximity to the BB emissions. In the previous work (Lawson et al., 2015), the MCE for the first $10 \mathrm{~h}$ of BB2 was calculated as 0.88 . However, later in $\mathrm{BB} 2$, a rainfall event led to changes in the $\mathrm{NMOC} / \mathrm{CO}$ and $\mathrm{BC} / \mathrm{CO}$ ratios. This suggests that during the course of $\mathrm{BB} 2$ the MCE decreased and thus EFs changed. As such, the use of fixed BB EFs in this work and in other models may lead to incorrect prediction of important species such as $\mathrm{O}_{3}$.

\subsubsection{Sensitivity of modelled concentrations to spatial variability}

The near-field proximity of the Robbins Island fire $(20 \mathrm{~km})$ to Cape Grim, the narrowness of the BB plume and the spatial complexity of the modelled wind fields around north Tasmania are likely to result in strong heterogeneity in the modelled concentrations surrounding Cape Grim. We investigated how much model spatial gradients vary by sampling TAPM-CTM output with $\mathrm{MCE}=0.89$ at four grid points located $1 \mathrm{~km}$ to the north, east, south and west of Cape Grim. 


\section{Primary species - CO}

Figure 10a shows a time series of the modelled CO output of the difference between Cape Grim and each grid point $1 \mathrm{~km}$ either side.

The plotted $\mathrm{CO}$ concentration is equal to the other location [CO] (N, S, E, W) - Cape Grim [CO].

The figure clearly shows that there are some large differences in the modelled concentrations of $\mathrm{CO}$ between grid points for both BB1 and BB2. Particularly large differences were seen for $\mathrm{BB} 2$, with the north grid point modelled concentrations in BB2 over $500 \mathrm{ppb}$ lower than at the Cape Grim grid point, while at the southerly grid point the modelled $\mathrm{CO}$ was up to $350 \mathrm{ppb}$ higher. Smaller differences of up to $250 \mathrm{ppb}$ between the east and Cape Grim grid points were observed for BB1. This indicates that the plume from the fire was narrow and had a highly variably impact on the area immediately surrounding Cape Grim.

Figure 10b shows the observed cumulative concentration of CO over the $29 \mathrm{~h}$ duration of BB2 at Cape Grim, as well as the modelled cumulative concentration at Cape Grim and at the four grid points either side. This figure shows the variability in concentration with both location and time. TAPMCTM's underestimation of the observed $\mathrm{CO}$ is visible by hour 20. TAPM-CTM begins to show differences in modelled cumulative $\mathrm{CO}$ concentrations between the five grid points (including Cape Grim) by hour 10. At the end of BB2, TAPM-CTM predicts that there are differences of 5-30\% between the cumulative modelled $\mathrm{CO}$ concentration at Cape Grim and the grid points to the north, east, south and west. This variability modelled between sites that are closely located highlights the challenges with modelling the impact of a near-field fire at a fixed single-point location. This also highlights the high spatial variability that may be missed in similar situations by using a coarser resolution model, which would dilute emissions in a larger grid box.

\section{Ozone $\left(\mathbf{O}_{3}\right)$}

Figure 10c shows a time series of the modelled $\mathrm{O}_{3}$ output of the difference between Cape Grim and each grid point $1 \mathrm{~km}$ either side, where plotted $\mathrm{O}_{3}$ concentration is equal to the other location $\left[\mathrm{O}_{3}\right](\mathrm{N}, \mathrm{S}, \mathrm{E}, \mathrm{W})$ - Cape Grim $\left[\mathrm{O}_{3}\right]$.

The modelled TAPM-CTM concentrations are very similar at all grid points when not influenced by $\mathrm{BB}$ emissions. The variability increases at the time of BB1 and BB2, with differences mostly within $2-3 \mathrm{ppb}$, but up to 15 and $10 \mathrm{ppb}$ at the east and west sites for BB1. This largest difference corresponds to the additional modelled $\mathrm{O}_{3}$ peak that was not observed and showed strong dependency on EF (see Sect. 3.1.2) and provides further evidence that local $\mathrm{BB}$ emissions drive this enhancement.

The TAPM-CTM output for $\mathrm{O}_{3}$ for BB1 (Fig. 7) shows $\mathrm{O}_{3}$ enhancement downwind of the fire at 11:00 and 13:00 on 16 February. The very localised and narrow $\mathrm{O}_{3}$ plume is
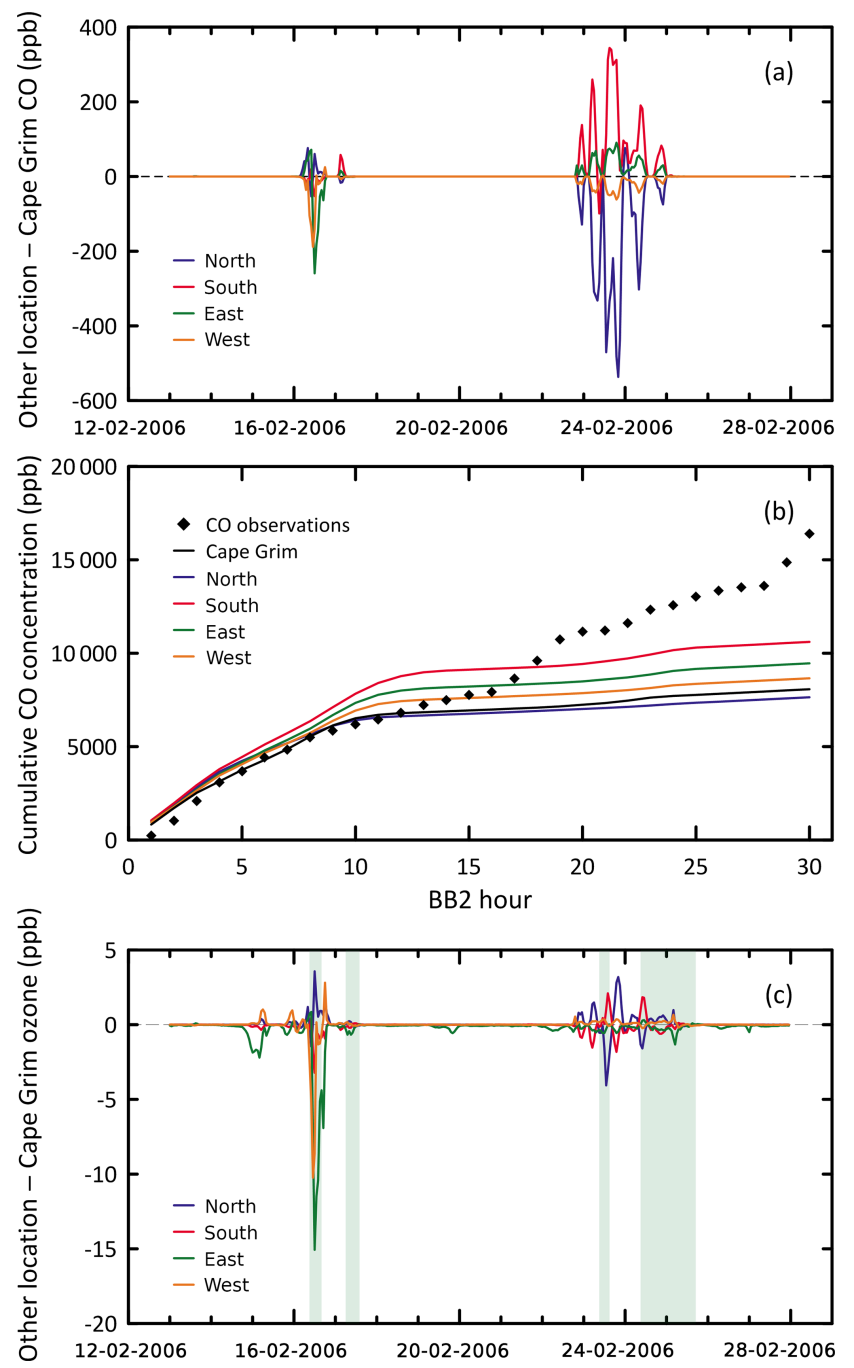

Figure 10. Simulated spatial variability using TAPM-CTM with $\mathrm{MCE}=0.89$ showing (a) time series of $\mathrm{CO}$ over 2 weeks of fire (BB1 and BB2 shown), (b) the observed and modelled cumulative concentration of $\mathrm{CO}$ over the $29 \mathrm{~h}$ duration of BB2 and (c) time series of $\mathrm{O}_{3}$ over the 2 weeks of fire. The four modelled $\mathrm{O}_{3}$ peaks at the Cape Grim grid point are shaded. Panels (a, c) show the difference between simulated concentrations at Cape Grim and at four surrounding grid points $1 \mathrm{~km}$ north, south, east and west of Cape Grim. Panel (b) shows simulated cumulative CO at Cape Grim and at four surrounding grid points. Observations are black symbols.

dispersed by the light $\left(2 \mathrm{~ms}^{-1}\right)$ and variable winds, and Cape Grim is on the edge of the $\mathrm{O}_{3}$ plume for much of this period, explaining the high variability seen in Fig. 6c.

In summary, there is a large amount of spatial variability in TAPM-CTM for primary species such as $\mathrm{CO}$ during the BB events, with differences of $>500 \mathrm{ppb}$ in grid points $1 \mathrm{~km}$ apart. This is due to the close proximity of the fire to the observation site and narrow-plume non-stationary meteorology. For $\mathrm{O}_{3}$, there is up to $15 \mathrm{ppb}$ of difference between grid 


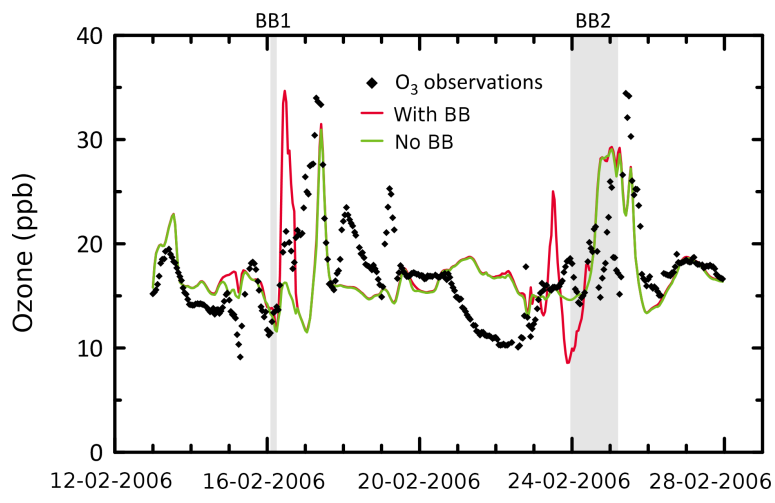

Figure 11. Simulated $\mathrm{O}_{3}$ concentration at Cape Grim with the Robbins Island fire emissions (red line) and without the fire emissions (green line). Observations are black symbols. The model used was TAPM-CTM with EF corresponding to $\mathrm{MCE}=0.89$. The periods corresponding to observed $\mathrm{BB} 1$ and $\mathrm{BB} 2$ are shaded.

points for a narrow $\mathrm{O}_{3}$ plume that is formed downwind of the fire.

The highly localised nature of the primary and in some cases secondary species seen here highlights the benefits of assessing spatial variability in situations with a closeproximity point source and a fixed receptor (measurement) site.

\subsection{Exploring plume chemistry and contribution from different sources}

\subsubsection{Drivers of $\mathrm{O}_{3}$ production}

In previous work on the Robbins Island fire, it was noted that the increases in $\mathrm{O}_{3}$ observed after both $\mathrm{BB} 1$ and $\mathrm{BB} 2$ were correlated with increased concentration of HFC-134a (Lawson et al., 2015). This indicated that transport of photochemically processed air from urban areas to Cape Grim was likely the main driver of the $\mathrm{O}_{3}$ observed, rather than BB emissions (Lawson et al., 2015). However, during BB1 in a calm sunny period with minimal urban influence, an increase in $\mathrm{O}_{3}$ was observed alongside a period of particle growth and elevated BC, suggesting possible BB influence. Normalised excess mixing ratios (NEMRs) observed during BB2 were also in the range of those observed elsewhere in young BB plumes (Lawson et al., 2015) (where NEMR is an excess mixing ratio normalised to a non-reactive co-emitted tracer, in this case CO; see Akagi et al., 2011).

To explore this further, TAPM-CTM was used to determine the degree to which the local fire emissions, and urban emissions from mainland Australia, were driving the observed $\mathrm{O}_{3}$ enhancements. The scenario with EF corresponding to $\mathrm{MCE}=0.89$ was used, as discussed previously.

Figure 11 shows the simulated ozone for all sources ("with BB") and all sources excluding the Robbins Island fire ("no BB"). There are two additional distinct ozone peaks in the

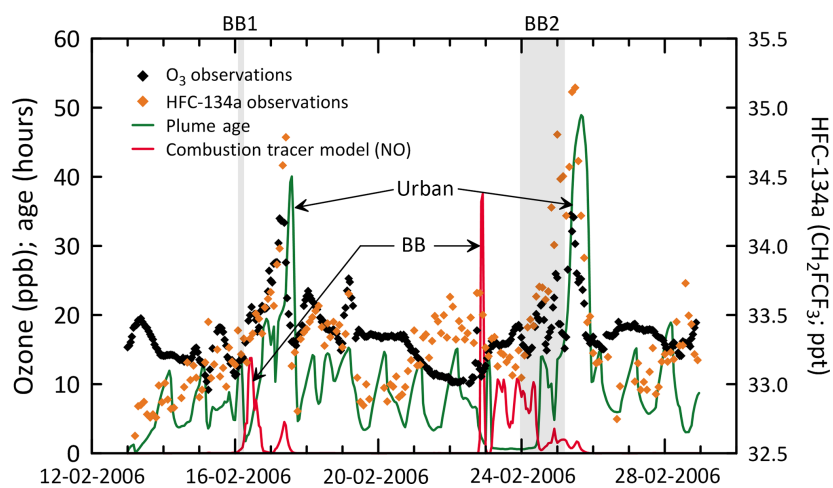

Figure 12. Simulated plume age (green line), simulated combustion tracer (NO) (red line), observed $\mathrm{O}_{3}$ (black symbols) and observed HFC-134a (orange symbols) over a 2-week duration of the fire. The modelled BB periods (red peaks) and impact of urban air from mainland Australia (green peaks) are labelled. The periods corresponding to observed BB1 and BB2 are shaded.

with BB simulation (Fig. 11). These occurred during or close to the plume strikes and are short-lived $(3$ and $5 \mathrm{~h}$ ) events. These same two peaks showed a strong dependence on model EF in Sect. 3.1.2. In contrast, the two peaks attributed to transport of air from mainland Australia are of longer duration and occur after the plume strikes.

Of the two modelled fire-derived $\mathrm{O}_{3}$ peaks, the first modelled peak (33 ppb) corresponds with a small (21 ppb) observed peak during BB1 (Period B in Lawson et al., 2015), but the second modelled fire-derived $\mathrm{O}_{3}$ peak is not observed. As shown in Fig. 7 and discussed in Sect. 3.1.3, according to TAPM-CTM the $\mathrm{O}_{3}$ plumes generated from fire emissions were narrow and showed a strong spatial variability. Given this, it is challenging for TAPM-CTM to predict the exact timing and magnitude of these highly variable BBgenerated $\mathrm{O}_{3}$ peaks impacting Cape Grim. This is likely why there is good agreement in timing and magnitude between model and observations for the large-scale, spatially homogeneous $\mathrm{O}_{3}$ plumes transported from mainland Australia but a lesser agreement for the locally formed, spatially variable $\mathrm{O}_{3}$ formed from local fire emissions.

In summary, TAPM-CTM suggests that the two largest observed $\mathrm{O}_{3}$ peaks following $\mathrm{BB} 1$ and $\mathrm{BB} 2$ were urban air transported from mainland Australia and some $\mathrm{O}_{3}$ formation was driven by emissions from the local fire event. TAPMCTM captures the magnitude and timing of the larger-scale urban-derived peaks well but is challenged by the timing and magnitude of $\mathrm{O}_{3}$ from local $\mathrm{BB}$ emissions.

\subsubsection{Plume age}

TAPM-CTM was used to estimate the physical age of air parcels reaching Cape Grim over the 2-week period of the Robbins Island fire. The method is similar to the Eulerian effective physical age of emission metric, accounting for mix- 
ing and chemical decay from Finch et al. (2014) and has been previously described in Keywood et al. (2015). Briefly, two model simulations were run for scenarios that included all sources of nitric oxide (NO) in Australia; the first treated $\mathrm{NO}$ as an unreactive tracer, the second with NO decaying at a constant first-order rate. The relative fraction of the emitted NO molecules remaining after $96 \mathrm{~h}$ was then inverted to give a molar-weighted plume age. As urban emissions are a larger NO source than $\mathrm{BB}$, this approach would weight the age in the favour of the urban emissions if air masses from these two sources were mixed. However, as shown in Fig. 11, there are distinct periods when BB or urban sources dominate. As there is little mixing of air from the two sources, there are unlikely to be issues with the calculated age being weighted towards one source. The modelled NO tracer (decayed version) modelled plume age (hours) and the observed $\mathrm{O}_{3}$. Direct BB1 and BB2 plume strikes can be clearly seen with increases in $\mathrm{NO}$ corresponding with a plume age of $0-2 \mathrm{~h}$. The plume age then gradually increases over $24 \mathrm{~h}$ in both cases, peaking at 15:00 on 17 February during BB1 (age of plume is $40 \mathrm{~h}$ ) and peaking at 17:00 on 25 February during BB2 (age of plume is $49 \mathrm{~h}$ ). The peak observed $\mathrm{O}_{3}$ enhancements correspond with the simulated plume age in both BB1 and BB2 (with an offset of $2 \mathrm{~h}$ for BB1) and the observed HFC-134a, suggesting that the plume that transported $\mathrm{O}_{3}$ from Melbourne to Cape Grim was approximately 2 days old. TAPM-CTM also simulates a smaller NO peak alongside the maximum plume age, indicating transport of decayed NO from the mainland to Cape Grim.

As reported in Lawson et al. (2015), during BB2 NEMRs of $\Delta \mathrm{O}_{3} / \Delta \mathrm{CO}$ ranged from 0.001 to 0.074 , in agreement with $\mathrm{O}_{3}$ enhancements observed in young $\mathrm{BB}$ plumes elsewhere (Yokelson et al., 2003, 2009). However, the modelling reported here suggests that almost all of the $\mathrm{O}_{3}$ observed during BB2 was of urban not BB origin. This suggests that NEMRs should not be used in isolation to identify the source of observed $\mathrm{O}_{3}$ enhancements and highlights the value of utilising air mass back trajectories and modelling to interpret the source of $\mathrm{O}_{3}$ enhancements where there are multiple emission sources.

\section{Summary and conclusions}

In this work we have used a unique set of opportunistic BB observations at Cape Grim Baseline Air Pollution Station to test the ability of CSIRO's high-resolution ( $400 \mathrm{~m}$ grid cell) CTM to reproduce primary $(\mathrm{CO}, \mathrm{BC})$ and secondary $\left(\mathrm{O}_{3}\right) \mathrm{BB}$ species in challenging non-stationary, inhomogeneous and near-field conditions. We tested the sensitivity of the CTM to three different parameters (meteorology, MCE and spatial variability) while holding the plume rise and the chemical mechanisms constant.

We found that meteorology, EF and spatial variability have a large influence on the modelled output mainly due to the close proximity of the fire to the receptor site (Cape Grim). The lower MCE $(\mathrm{MCE}=0.89)$ TAPM-CTM model simulation provided the best agreement with the observed concentrations, in agreement with the MCE calculated from observations of 0.88 (Lawson et al., 2015). The changing EFs, in particular NO dependency on MCE, had a major influence on the simulated $\mathrm{O}_{3}$ concentrations, with a tendency of the models in some configurations to fail to simulate observed $\mathrm{O}_{3}$ peaks and to simulate complete titration of $\mathrm{O}_{3}$ that was not observed. As shown in the previous work (Lawson et al., 2015), minor rainfall events have the potential to significantly alter EF due to changes in combustion processes. This work suggests that varying model EF has a major impact on whether the models predict production or destruction of $\mathrm{O}_{3}$, which is particularly important at a receptor site in close proximity to the $\mathrm{BB}$ emissions. Models that assume a fixed $\mathrm{EF}$ for $\mathrm{O}_{3}$ precursor species in an environment with temporally and spatially variable EF may therefore be challenged to correctly predict the behaviour of important species such as $\mathrm{O}_{3}$.

There were significant differences in model output between Cape Grim and grid points $1 \mathrm{~km}$ away, highlighting the narrowness of the plume and the challenge of predicting when the plume would impact the station. This also highlights the high spatial variability, which may be missed in similar situations by using a coarser-resolution model that would dilute emissions in a larger grid box.

TAPM-CTM was used to distinguish the influence of the two sources on the observed $\mathrm{O}_{3}$ enhancements that followed BB1 and BB2. Transport of a 2-day-old urban plume some $300 \mathrm{~km}$ away from Melbourne was the main source of the $\mathrm{O}_{3}$ enhancement observed at Cape Grim over the 2-week period of the fire. Despite NEMRs of $\Delta \mathrm{O}_{3} / \Delta \mathrm{CO}$ during BB2 being similar to those observed in young BB plumes elsewhere, this work suggests that NEMRs should not be used in isolation to identify the source of observed $\mathrm{O}_{3}$ enhancements and highlights the value of utilising air mass back trajectories and modelling to interpret the source of $\mathrm{O}_{3}$ enhancements where there are multiple emission sources.

Data availability. The underlying research data can be accessed upon request to the corresponding author (Sarah Lawson; sarah.lawson@csiro.au).

\section{The Supplement related to this article is available online at https://doi.org/10.5194/acp-17-11707-2017- supplement.}

Competing interests. The authors declare that they have no conflict of interest. 
Acknowledgements. The Cape Grim program, established by the Australian Government to monitor and study global atmospheric composition, is a joint responsibility of the Bureau of Meteorology (BOM) and the Commonwealth Scientific and Industrial Research Organisation (CSIRO). We thank the staff at Cape Grim and at CSIRO Oceans and Atmosphere for providing observation data for this work. Thank you to Nada Derek for producing figures, Mick Meyer for providing fire scar information and Suzie Molloy for providing advice on ozone observation data. Finally, we thank the three anonymous reviewers for their helpful suggestions and comments.

Edited by: Alex B. Guenther

Reviewed by: three anonymous referees

\section{References}

Akagi, S. K., Yokelson, R. J., Wiedinmyer, C., Alvarado, M. J., Reid, J. S., Karl, T., Crounse, J. D., and Wennberg, P. O.: Emission factors for open and domestic biomass burning for use in atmospheric models, Atmos. Chem. Phys., 11, 4039-4072, https://doi.org/10.5194/acp-11-4039-2011, 2011.

Akagi, S. K., Yokelson, R. J., Burling, I. R., Meinardi, S., Simpson, I., Blake, D. R., McMeeking, G. R., Sullivan, A., Lee, T., Kreidenweis, S., Urbanski, S., Reardon, J., Griffith, D. W. T., Johnson, T. J., and Weise, D. R.: Measurements of reactive trace gases and variable $\mathrm{O}_{3}$ formation rates in some South Carolina biomass burning plumes, Atmos. Chem. Phys., 13, 1141-1165, https://doi.org/10.5194/acp-13-1141-2013, 2013.

Alvarado, M. J. and Prinn, R. G.: Formation of ozone and growth of aerosols in young smoke plumes from biomass burning: 1 . Lagrangian parcel studies, J. Geophys. Res.-Atmos., 114, D09306, https://doi.org/10.1029/2008jd011144, 2009

Alvarado, M. J., Wang, C., and Prinn, R. G.: Formation of ozone and growth of aerosols in young smoke plumes from biomass burning: 2. Three-dimensional Eulerian studies, J. Geophys. Res.Atmos., 114, D09307, https://doi.org/10.1029/2008jd011186, 2009.

Alvarado, M. J., Lonsdale, C. R., Yokelson, R. J., Akagi, S. K., Coe, H., Craven, J. S., Fischer, E. V., McMeeking, G. R., Seinfeld, J. H., Soni, T., Taylor, J. W., Weise, D. R., and Wold, C. E.: Investigating the links between ozone and organic aerosol chemistry in a biomass burning plume from a prescribed fire in California chaparral, Atmos. Chem. Phys., 15, 6667-6688, https://doi.org/10.5194/acp-15-6667-2015, 2015.

Anderson, D. C., Nicely, J. M., Salawitch, R. J., Canty, T. P., Dickerson, R. R., Hanisco, T. F., Wolfe, G. M., Apel, E. C., Atlas, E., Bannan, T., Bauguitte, S., Blake, N. J., Bresch, J. F., Campos, T. L., Carpenter, L. J., Cohen, M. D., Evans, M., Fernandez, R. P., Kahn, B. H., Kinnison, D. E., Hall, S. R., Harris, N. R., Hornbrook, R. S., Lamarque, J. F., Le Breton, M., Lee, J. D., Percival, C., Pfister, L., Pierce, R. B., Riemer, D. D., Saiz-Lopez, A., Stunder, B. J., Thompson, A. M., Ullmann, K., Vaughan, A., and Weinheimer, A. J.: A pervasive role for biomass burning in tropical high ozone/low water structures, Nat. Commun., 7, 10267, https://doi.org/10.1038/ncomms10267, 2016.
Andreae, M. O. and Merlet, P.: Emission of trace gases and aerosols from biomass burning, Global Biogeochem. Cy., 15, 955-966, https://doi.org/10.1029/2000gb001382, 2001.

Andreae, M. O., Artaxo, P., Brandao, C., Carswell, F. E., Ciccioli, P., da Costa, A. L., Culf, A. D., Esteves, J. L., Gash, J. H. C., Grace, J., Kabat, P., Lelieveld, J., Malhi, Y., Manzi, A. O., Meixner, F. X., Nobre, A. D., Nobre, C., Ruivo, M., SilvaDias, M. A., Stefani, P., Valentini, R., von Jouanne, J., and Waterloo, M. J.: Biogeochemical cycling of carbon, water, energy, trace gases, and aerosols in Amazonia: the LBAEUSTACH experiments, J. Geophys. Res.-Atmos., 107, 8066, https://doi.org/10.1029/2001jd000524, 2002.

Arnold, S. R., Emmons, L. K., Monks, S. A., Law, K. S., Ridley, D. A., Turquety, S., Tilmes, S., Thomas, J. L., Bouarar, I., Flemming, J., Huijnen, V., Mao, J., Duncan, B. N., Steenrod, S., Yoshida, Y., Langner, J., and Long, Y.: Biomass burning influence on high-latitude tropospheric ozone and reactive nitrogen in summer 2008: a multi-model analysis based on POLMIP simulations, Atmos. Chem. Phys., 15, 6047-6068, https://doi.org/10.5194/acp-15-6047-2015, 2015.

Artaxo, P., Rizzo, L. V., Brito, J. F., Barbosa, H. M. J., Arana, A., Sena, E. T., Cirino, G. G., Bastos, W., Martin, S. T., and Andreae, M. O.: Atmospheric aerosols in Amazonia and land use change: from natural biogenic to biomass burning conditions, Faraday Discuss., 165, 203-235, https://doi.org/10.1039/c3fd00052d, 2013.

Azzi, M., Cope, M., and Rae, M.: Sustainable Energy Deployment within the Greater Metropolitan Region, NSW-Environmental Trust, CSIRO, North Ryde, Australia, 2012.

Barrett, D. J.: Steady state turnover time of carbon in the Australian terrestrial biosphere, Global Biogeochem. Cy., 16, 55-51-55-21, https://doi.org/10.1029/2002gb001860, 2002.

Broome, R. A., Cope, M. E., Goldsworthy, B., Goldsworthy, L., Emmerson, K., Jegasothy, E., and Morgan, G. G.: The mortality effect of ship-related fine particulate matter in the Sydney greater metropolitan region of NSW, Australia, Environ. Int., 87, 85-93, https://doi.org/10.1016/j.envint.2015.11.012, 2016.

Castellanos, P., Boersma, K. F., and van der Werf, G. R.: Satellite observations indicate substantial spatiotemporal variability in biomass burning $\mathrm{NO}_{x}$ emission factors for South America, Atmos. Chem. Phys., 14, 3929-3943, https://doi.org/10.5194/acp14-3929-2014, 2014.

Cope, M., Lee, S., Noonan, J., Lilley, B., Hess, G. D., and Azzi, M.: Chemical Transport Model - Technical Description, Centre for Australian Weather and Climate Research, Technical Report No. 15, CSIRO and the Bureau of Meteorology, Melbourne, Australia, 2009.

Cope, M., Keywood, M., Emmerson, K., Galbally, I. E., Boast, K., Chambers, S., Cheng, M., Crumeyrolle, S., Dunne, E., Fedele, R., Gillett, R., Griffiths, A., Harnwell, J., Katzfey, J., Hess, D., Lawson, S. J., Miljevic, B., Molloy, S., Powell, J., Reisen, F., Ristovski, Z., Selleck, P., Ward, J., Zhang, C., and Zeng, J.: Sydney Particle Study Stage II, available at: http://141 243.32.146/resources/aqms/SydParticleStudy10-13.pdf (last access: 28 September 2017), 2014.

Cope, M. E., Hess, G. D., Lee, S., Tory, K., Azzi, M., Carras, J., Lilley, W., Manins, P. C., Nelson, P., Ng, L., Puri, K., Wong, N., Walsh, S., and Young, M.: The Australian Air Quality Forecasting System. Part I: Project description and early outcomes, 
J. Appl. Meteorol., 43, 649-662, https://doi.org/10.1175/2093.1, 2004.

Delaney, W. and Marshall, A. G.: Victorian Air Emissions Inventory for 2006, 20th International Clean Air and Environment Conference, Auckland, Clean Air Society of Australia and New Zealand, Auckland, New Zealand, 31 July-2 August 2011.

Dennekamp, M., Straney, L. D., Erbas, B., Abramson, M. J., Keywood, M., Smith, K., Sim, M. R., Glass, D. C., Del Monaco, A., Haikerwal, A., and Tonkin, A. M.: Forest fire smoke exposures and out-of-hospital cardiac arrests in Melbourne, Australia: a case-crossover study, Environ. Health Persp., 123, 959-964, https://doi.org/10.1289/ehp.1408436, 2015.

Donahue, N. M., Robinson, A. L., Stanier, C. O., and Pandis, S. N.: Coupled partitioning, dilution, and chemical aging of semivolatile organics, Environ. Sci. Technol., 40, 2635-2643, https://doi.org/10.1021/es052297c, 2006.

Draxler, R. R. and Hess, G. D.: Description of the HYSPLIT_4 Modeling System, NOAA Technical Memorandum ERL ARL224, Air Resources Laboratory Silver Spring, Maryland, USA, 1997.

Emmerson, K. M., Galbally, I. E., Guenther, A. B., Paton-Walsh, C., Guerette, E.-A., Cope, M. E., Keywood, M. D., Lawson, S. J., Molloy, S. B., Dunne, E., Thatcher, M., Karl, T., and Maleknia, S. D.: Current estimates of biogenic emissions from eucalypts uncertain for southeast Australia, Atmos. Chem. Phys., 16, 6997-7011, https://doi.org/10.5194/acp-16-6997-2016, 2016.

Emmons, L. K., Apel, E. C., Lamarque, J.-F., Hess, P. G., Avery, M., Blake, D., Brune, W., Campos, T., Crawford, J., DeCarlo, P. F., Hall, S., Heikes, B., Holloway, J., Jimenez, J. L., Knapp, D. J., Kok, G., Mena-Carrasco, M., Olson, J., O’Sullivan, D., Sachse, G., Walega, J., Weibring, P., Weinheimer, A., and Wiedinmyer, C.: Impact of Mexico City emissions on regional air quality from MOZART-4 simulations, Atmos. Chem. Phys., 10, 6195-6212, https://doi.org/10.5194/acp-10-6195-2010, 2010.

Ferek, R. J., Reid, J. S., Hobbs, P. V., Blake, D. R., and Liousse, C.: Emission factors of hydrocarbons, halocarbons, trace gases and particles from biomass burning in Brazil, J. Geophys. Res.Atmos., 103, 32107-32118, https://doi.org/10.1029/98JD00692, 1998.

Finch, D. P., Palmer, P. I., and Parrington, M.: Origin, variability and age of biomass burning plumes intercepted during BORTAS-B, Atmos. Chem. Phys., 14, 13789-13800, https://doi.org/10.5194/acp-14-13789-2014, 2014.

Flannigan, M. D., Krawchuk, M. A., de Groot, W. J., Wotton, B. M., and Gowman, L. M.: Implications of changing climate for global wildland fire, Int. J. Wildland Fire, 18, 483-507, https://doi.org/10.1071/WF08187, 2009.

Fountoukis, C. and Nenes, A.: ISORROPIA II: a computationally efficient thermodynamic equilibrium model for $\mathrm{K}^{+}{ }_{-}$ $\mathrm{Ca}^{2+}-\mathrm{Mg}^{2+}-\mathrm{NH}_{4}{ }^{+}-\mathrm{Na}^{+}-\mathrm{SO}_{4}{ }^{2-}-\mathrm{NO}_{3}{ }^{-}-\mathrm{Cl}^{-}-\mathrm{H}_{2} \mathrm{O}$ aerosols, Atmos. Chem. Phys., 7, 4639-4659, https://doi.org/10.5194/acp7-4639-2007, 2007.

Freitas, S. R., Longo, K. M., Chatfield, R., Latham, D., Silva Dias, M. A. F., Andreae, M. O., Prins, E., Santos, J. C., Gielow, R., and Carvalho Jr., J. A.: Including the sub-grid scale plume rise of vegetation fires in low resolution atmospheric transport models, Atmos. Chem. Phys., 7, 3385-3398, https://doi.org/10.5194/acp7-3385-2007, 2007.
Galbally, I. E., Meyer, C. P., Bentley, S. T., Lawson, S. J., and Baly, S. B.: Reactive gases in near surface air at Cape Grim, 2005-2006, in: Baseline Atmospheric Program Australia 20052006, edited by: Cainey, J. M., Derek, N., and Krummel, P. B., The Australian Bureau of Meteorology Melbourne, Australia, available: http://www.bom.gov.au/inside/cgbaps/baseline. shtml (last access: 28 September 2017), 77-79, 2007.

Galbally, I. E., Cope, M., Lawson, S. J., Bentley, S. T., Cheng, M., Gillet, R. W., Selleck, P., Petraitis, B., Dunne, E., and Lee, S.: Sources of Ozone Precursors and Atmospheric Chemistry in a Typical Australian City, available at: http://pandora.nla. gov.au/pan/97227/20090326-1709/www.environment.gov.au/ atmosphere/airquality/publications/ozone-precursors.html (last access: 28 September 2017), 2008.

Giglio, L., Randerson, J. T., and van der Werf, G. R.: Analysis of daily, monthly, and annual burned area using the fourthgeneration global fire emissions database (GFED4), J. Geophys. Res.-Biogeo., 118, 317-328, https://doi.org/10.1002/jgrg.20042, 2013.

Gong, S. L.: A parameterization of sea-salt aerosol source function for sub- and super-micron particles, Global Biogeochem. Cy., 17, 1097, https://doi.org/10.1029/2003gb002079, 2003.

Goodrick, S. L., Achtemeier, G. L., Larkin, N. K., Liu, Y., and Strand, T. M.: Modelling smoke transport from wildland fires: a review, Int. J. Wildland Fire, 22, 83-94, https://doi.org/10.1071/wf11116, 2013.

Gras, J. L.: Particles Program Report, in: Baseline Atmospheric Program Australia 2005-2006, The Australian Bureau of Meteorology, Melbourne, Australia, available at: http://www.bom.gov.au/ inside/cgbaps/baseline.shtml (last access: 28 September 2017), 85-86, 2007.

Hecobian, A., Liu, Z., Hennigan, C. J., Huey, L. G., Jimenez, J. L., Cubison, M. J., Vay, S., Diskin, G. S., Sachse, G. W., Wisthaler, A., Mikoviny, T., Weinheimer, A. J., Liao, J., Knapp, D. J., Wennberg, P. O., Kürten, A., Crounse, J. D., Clair, J. St., Wang, Y., and Weber, R. J.: Comparison of chemical characteristics of 495 biomass burning plumes intercepted by the NASA DC-8 aircraft during the ARCTAS/CARB-2008 field campaign, Atmos. Chem. Phys., 11, 13325-13337, https://doi.org/10.5194/acp-1113325-2011, 2011.

Hess, G. D.: A photochemical model for air quality assessment: model description and verification, Atmos. Environ., 23, 643660, https://doi.org/10.1016/0004-6981(89)90013-9, 1989.

Hurley, P.: Development and verification of TAPM, in: Air Pollution Modeling and Its Application XIX, edited by: Borrego, C. and Miranda, A. I., Springer Netherlands, Dordrecht, 208-216, 2008a.

Hurley, P. J.: TAPM V4. Part 1. Technical Description, CSIRO Marine and Atmospheric Research Internal Report, CSIRO Oceans and Atmosphere, Aspendale, Australia, 2008b.

Jaffe, D. A. and Wigder, N. L.: Ozone production from wildfires: a critical review, Atmos. Environ., 51, 1-10, https://doi.org/10.1016/j.atmosenv.2011.11.063, 2012.

Jost, C., Trentmann, J., Sprung, D., Andreae, M. O., McQuaid, J. B., and Barjat, H.: Trace gas chemistry in a young biomass burning plume over Namibia: observations and model simulations, J. Geophys. Res.-Atmos., 108, 8482, https://doi.org/10.1029/2002jd002431, 2003. 
Kaiser, J. W., Heil, A., Andreae, M. O., Benedetti, A., Chubarova, N., Jones, L., Morcrette, J.-J., Razinger, M., Schultz, M. G., Suttie, M., and van der Werf, G. R.: Biomass burning emissions estimated with a global fire assimilation system based on observed fire radiative power, Biogeosciences, 9, 527-554, https://doi.org/10.5194/bg-9-527-2012, 2012.

Keywood, M., Guyes, H., Selleck, P., and Gillett, R.: Quantification of secondary organic aerosol in an Australian urban location, Environ. Chem., 8, 115-126, https://doi.org/10.1071/en10100, 2011a.

Keywood, M., Kanakidou, M., Stohl, A., Dentener, F., Grassi, G., Meyer, C. P., Torseth, K., Edwards, D., Thompson, A., Lohmann, U., and Burrows, J. P.: Fire in the air-biomass burning impacts in a changing climate, Crit. Rev. Env. Sci. Tec., 43, 40-83, https://doi.org/10.1080/10643389.2011.604248, $2011 \mathrm{~b}$.

Keywood, M., Cope, M., Meyer, C. P. M., Iinuma, Y., and Emmerson, K.: When smoke comes to town: the impact of biomass burning smoke on air quality, Atmos. Environ., 121, 13-21, https://doi.org/10.1016/j.atmosenv.2015.03.050, 2015.

Korontzi, S., Ward, D. E., Susott, R. A., Yokelson, R. J., Justice, C. O., Hobbs, P. V., Smithwick, E. A. H., and Hao, W. M.: Seasonal variation and ecosystem dependence of emission factors for selected trace gases and $\mathrm{PM}_{2.5}$ for southern African savanna fires, J. Geophys. Res.-Atmos., 108, 4758, https://doi.org/10.1029/2003JD003730, 2003.

Krummel, P. B., Fraser, P., Steele, L. P., Porter, L. W., Derek, N., Rickard, C., Dunse, B. L., Langenfelds, R. L., Miller, B. R., Baly, S. B., and McEwan, S.: The AGAGE in situ program for non- $\mathrm{CO}_{2}$ greenhouse gases at Cape Grim, 2005-2006: Methane, nitrous oxide, carbon monoxide, hydrogen, CFCs, HCFCs, HFCs, PFCs, halons, chlorocarbons, hydrocarbons and sulphur hexafluoride, in: Baseline Atmospheric Program Australia 2005-2006, The Australian Bureau of Meteorology, Melbourne, Australia, available at: http://www.bom.gov.au/inside/ cgbaps/baseline.shtml (last access: 28 September 2017), 2007.

Lawson, S. J., Keywood, M. D., Galbally, I. E., Gras, J. L., Cainey, J. M., Cope, M. E., Krummel, P. B., Fraser, P. J., Steele, L. P., Bentley, S. T., Meyer, C. P., Ristovski, Z., and Goldstein, A. H.: Biomass burning emissions of trace gases and particles in marine air at Cape Grim, Tasmania, Atmos. Chem. Phys., 15, 1339313411, https://doi.org/10.5194/acp-15-13393-2015, 2015.

Lei, W., Li, G., and Molina, L. T.: Modeling the impacts of biomass burning on air quality in and around Mexico City, Atmos. Chem. Phys., 13, 2299-2319, https://doi.org/10.5194/acp13-2299-2013, 2013.

Lu, H. and Shao, Y. P.: A new model for dust emission by saltation bombardment, J. Geophys. Res.-Atmos., 104, 16827-16841, https://doi.org/10.1029/1999jd900169, 1999.

Luhar, A. K., Mitchell, R. M., Meyer, C. P., Qin, Y., Campbell, S., Gras, J. L., and Parry, D.: Biomass burning emissions over northern Australia constrained by aerosol measurements: II - Model validation, and impacts on air quality and radiative forcing, Atmos. Environ., 42, 1647-1664, https://doi.org/10.1016/j.atmosenv.2007.12.040, 2008.

Mason, S. A., Trentmann, J., Winterrath, T., Yokelson, R. J., Christian, T. J., Carlson, L. J., Warner, T. R., Wolfe, L. C., and Andreae, M. O.: Intercomparison of two box models of the chemical evolution in biomass-burning smoke plumes, J. Atmos. Chem., 55, 273-297, https://doi.org/10.1007/s10874-006-9039-5, 2006.
McGregor, J. L.: Recent developments in variable-resolution global climate modelling, Climatic Change, 129, 369-380, https://doi.org/10.1007/s10584-013-0866-5, 2015.

Meyer, C. P., Luhar, A. K., and Mitchell, R. M.: Biomass burning emissions over northern Australia constrained by aerosol measurements: I - Modelling the distribution of hourly emissions, Atmos. Environ., 42, 1629-1646, https://doi.org/10.1016/j.atmosenv.2007.10.089, 2008.

Meyer, C. P., Cook, G. D., Reisen, F., Smith, T. E. L., Tattaris, M., Russell-Smith, J., Maier, S., Yates, C. P., and Wooster, M. J.: Direct measurements of the seasonality of emission factors from savanna fires in northern Australia, J. Geophys. Res.-Atmos., 117, D20305, https://doi.org/10.1029/2012JD017671, 2012.

Ortega, A. M., Day, D. A., Cubison, M. J., Brune, W. H., Bon, D., de Gouw, J. A., and Jimenez, J. L.: Secondary organic aerosol formation and primary organic aerosol oxidation from biomassburning smoke in a flow reactor during FLAME-3, Atmos. Chem. Phys., 13, 11551-11571, https://doi.org/10.5194/acp-1311551-2013, 2013.

Pacifico, F., Folberth, G. A., Sitch, S., Haywood, J. M., Rizzo, L. V., Malavelle, F. F., and Artaxo, P.: Biomass burning related ozone damage on vegetation over the Amazon forest: a model sensitivity study, Atmos. Chem. Phys., 15, 2791-2804, https://doi.org/10.5194/acp-15-2791-2015, 2015.

Parrington, M., Palmer, P. I., Henze, D. K., Tarasick, D. W., Hyer, E. J., Owen, R. C., Helmig, D., Clerbaux, C., Bowman, K. W., Deeter, M. N., Barratt, E. M., Coheur, P.-F., Hurtmans, D., Jiang, Z., George, M., and Worden, J. R.: The influence of boreal biomass burning emissions on the distribution of tropospheric ozone over North America and the North Atlantic during 2010, Atmos. Chem. Phys., 12, 2077-2098, https://doi.org/10.5194/acp-12-2077-2012, 2012.

Paugam, R., Wooster, M., Freitas, S., and Val Martin, M.: A review of approaches to estimate wildfire plume injection height within large-scale atmospheric chemical transport models, Atmos. Chem. Phys., 16, 907-925, https://doi.org/10.5194/acp-16907-2016, 2016.

Reid, C. E., Brauer, M., Johnston, F. H., Jerrett, M., Balmes, J. R., and Elliott, C. T.: Critical review of health impacts of wildfire smoke exposure, Environ. Health Persp., 124, 1334-1343, https://doi.org/10.1289/ehp.1409277, 2016.

Reid, J. S., Hyer, E. J., Prins, E. M., Westphal, D. L., Zhang, J., Wang, J., Christopher, S. A., Curtis, C. A., Schmidt, C. C., Eleuterio, D. P., Richardson, K. A., and Hoffman, J. P.: Global monitoring and forecasting of biomass-burning smoke: description of and lessons from the Fire Locating and Modeling of Burning Emissions (FLAMBE) program, IEEE J. Sel. Top. Appl., 2, 144-162, https://doi.org/10.1109/JSTARS.2009.2027443, 2009.

Reisen, F., Meyer, C. P., McCaw, L., Powell, J. C., Tolhurst, K., Keywood, M. D., and Gras, J. L.: Impact of smoke from biomass burning on air quality in rural communities in southern Australia, Atmos. Environ., 45, 3944-3953, https://doi.org/10.1016/j.atmosenv.2011.04.060, 2011.

Reisen, F., Duran, S. M., Flannigan, M., Elliott, C., and Rideout, K.: Wildfire smoke and public health risk, Int. J. Wildland Fire, 24, 1029, https://doi.org/10.1071/wf15034, 2015.

Sarwar, G., Luecken, D., Yarwood, G., Whitten, G. Z., and Carter, W. P. L.: Impact of an updated carbon bond mechanism on predictions from the CMAQ modeling sys- 
tem: preliminary assessment, J. Appl. Meteorol., 47, 3-14, https://doi.org/10.1175/2007jamc1393.1, 2008.

Sarwar, G., Appel, K. W., Carlton, A. G., Mathur, R., Schere, K., Zhang, R., and Majeed, M. A.: Impact of a new condensed toluene mechanism on air quality model predictions in the US, Geosci. Model Dev., 4, 183-193, https://doi.org/10.5194/gmd-4183-2011, 2011.

Seinfeld, J. H. and Pandis, S. N.: Atmospheric Chemistry Physics: From Air Pollution to Climate Change, Wiley, New York, xxvii, p. $1326,1998$.

Smagorinsky, J.: General circulation experiments with the primitive equations, Mon. Weather Rev., 91, 99-164, https://doi.org/10.1175/15200493(1963)091<0099:GCEWTP>2.3.CO;2, 1963.

Trentmann, J., Yokelson, R. J., Hobbs, P. V., Winterrath, T., Christian, T. J., Andreae, M. O., and Mason, S. A.: An analysis of the chemical processes in the smoke plume from a savanna fire, J. Geophys. Res.-Atmos., 110, D12301, https://doi.org/10.1029/2004jd005628, 2005.

Tsimpidi, A. P., Karydis, V. A., Zavala, M., Lei, W., Molina, L., Ulbrich, I. M., Jimenez, J. L., and Pandis, S. N.: Evaluation of the volatility basis-set approach for the simulation of organic aerosol formation in the Mexico City metropolitan area, Atmos. Chem. Phys., 10, 525-546, https://doi.org/10.5194/acp-10-5252010, 2010.

Urbanski, S. P.: Combustion efficiency and emission factors for wildfire-season fires in mixed conifer forests of the northern Rocky Mountains, US, Atmos. Chem. Phys., 13, 7241-7262, https://doi.org/10.5194/acp-13-7241-2013, 2013.

van Leeuwen, T. T. and van der Werf, G. R.: Spatial and temporal variability in the ratio of trace gases emitted from biomass burning, Atmos. Chem. Phys., 11, 3611-3629, https://doi.org/10.5194/acp-11-3611-2011, 2011.

van Leeuwen, T. T., Peters, W., Krol, M. C., and van der Werf, G. R.: Dynamic biomass burning emission factors and their impact on atmospheric CO mixing ratios, J. Geophys. Res.-Atmos., 118, 6797-6815, https://doi.org/10.1002/jgrd.50478, 2013.
Walcek, C. J.: Minor flux adjustment near mixing ratio extremes for simplified yet highly accurate monotonic calculation of tracer advection, J. Geophys. Res.-Atmos., 105, 9335-9348, https://doi.org/10.1029/1999JD901142, 2000.

Wigder, N. L., Jaffe, D. A., and Saketa, F. A.: Ozone and particulate matter enhancements from regional wildfires observed at Mount Bachelor during 2004-2011, Atmos. Environ., 75, 24-31, https://doi.org/10.1016/j.atmosenv.2013.04.026, 2013.

Yokelson, R. J., Bertschi, I. T., Christian, T. J., Hobbs, P. V., Ward, D. E., and Hao, W. M.: Trace gas measurements in nascent, aged, and cloud-processed smoke from African savanna fires by airborne Fourier transform infrared spectroscopy (AFTIR), J. Geophys. Res.-Atmos., 108, 8478, https://doi.org/10.1029/2002jd002322, 2003.

Yokelson, R. J., Karl, T., Artaxo, P., Blake, D. R., Christian, T. J., Griffith, D. W. T., Guenther, A., and Hao, W. M.: The Tropical Forest and Fire Emissions Experiment: overview and airborne fire emission factor measurements, Atmos. Chem. Phys., 7, 5175-5196, https://doi.org/10.5194/acp-7-5175-2007, 2007.

Yokelson, R. J., Crounse, J. D., DeCarlo, P. F., Karl, T., Urbanski, S., Atlas, E., Campos, T., Shinozuka, Y., Kapustin, V., Clarke, A. D., Weinheimer, A., Knapp, D. J., Montzka, D. D., Holloway, J., Weibring, P., Flocke, F., Zheng, W., Toohey, D., Wennberg, P. O., Wiedinmyer, C., Mauldin, L., Fried, A., Richter, D., Walega, J., Jimenez, J. L., Adachi, K., Buseck, P. R., Hall, S. R., and Shetter, R.: Emissions from biomass burning in the Yucatan, Atmos. Chem. Phys., 9, 5785-5812, https://doi.org/10.5194/acp-9-57852009, 2009.

Yokelson, R. J., Burling, I. R., Urbanski, S. P., Atlas, E. L., Adachi, K., Buseck, P. R., Wiedinmyer, C., Akagi, S. K., Toohey, D. W., and Wold, C. E.: Trace gas and particle emissions from open biomass burning in Mexico, Atmos. Chem. Phys., 11, 67876808, https://doi.org/10.5194/acp-11-6787-2011, 2011. 